\title{
Brachiopod Fauna of
}

\section{Saturday Mountain Formation}

Southern Lemhi Range

\section{Idaho}

GEOLOGIGAL SURVEY PROFESIONAL PAPER 294-L 


\section{Brachiopod Fauna of}

\section{Saturday Mountain Formation}

\section{Southern Lemhi Range}

\section{Idaho}

By REUBEN J. ROSS, JR.

SHORTER CONTRIBUTIONS TO GENERAL GEOLOGY

GEOLOGICAL SURVEY PROFESIONAL PAPER 294-L

Descriptions and stereophotographic

illustrations of IO species of brachiopods,

and correlations with other

Ordovician formations

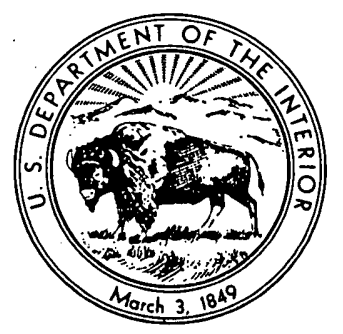

UNITED STATES GOVERNMENT PRINTING OFFICE, WASHINGTON : 1959 


\section{UNITED STATES DEPARTMENT OF THE INTERIOR}

FRED A. SEATON, Secretary

\section{GEOLOGIGAL SURVEY}

Thomas B. Nolan, Director

For sale by the Superintendent of Documents, U. S. Government Printing Office Washington 25, D. C. 


\section{CONTENTS}

Abstract._.

Introduction

Scope of the investigation

Acknowledgments

Stereophotography of the specimens

Fossil collecting localities _.

Dating of Saturday Mountain formation based on previous evidence

Composition and significance of the brachiopod fauna

Composition of the fauna.

Age of the fauna...

Ecologic significance of the fauna

Systematic descriptions of the brachiopods.

Class Articulata.

Superfamily Orthacea.

Family Plectorthidae

Subfamily Platystrophinae

Genus Platystrophia

Family Hesperorthidae.

Subfamily Hesperorthinae.

Genus Lordorthis, new genus.

Subfamily Glyptorthinae.

Genus Glyptorthis.

Family Dinorthidae

Genus Plaesiomys

Genus Austinella._.....

Superfamily Rhynchonellacea.

Superfamily Spiriferacea.

Genus Zygospira

Superfamily Strophomenacea

Genus Thaerodonta.

Superfamily Dalmanellacea

Genus Diceromyonia

References cited

Index

\section{ILLUSTRATIONS}

[Plates 54-56 follow p. 463]

Plates 54-56. Brachiopod fauna of Saturday Mountain formation.

Figure 145. Fossil collecting localities in the Saturday Mountain formation, southern Lemhi Range, Idaho.

146. Scatter diagram of length: width in Plaesiomys subquadratus. Specimens of other species and subspecies plotted for comparison

147. Scatter diagram of length: width in Plaesiomys subquadratus, brachial valves only

148. Scatter diagram of length: width in $P$. subquadratus subsp. idahoensis, brachial valves only

149. Scatter diagram of length: width in $P$. subquadratus, pedicle valves only

150. Scatter diagram of length: width in $P$. subquadratus subsp. idahoensis, pedicle valves only

151. Scatter diagram of hinge width: total width in Plaesiomys subquadratus

152. Scatter diagram of hinge width: total width in $P$. subquadratus subsp. idahoensis

153. Scatter diagram of number of costellae in $10 \mathrm{~mm}$ at front of valve: length of valve in mm for Plaesiomys 8ubquadratus.

154. Scatter diagram of number of costellae in $10 \mathrm{~mm}$ at front of valve: length of valve in mm for $P$. subquadratus subsp. idahoensis.

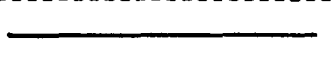

\section{TABLES}

TABLE 1. Distribution of brachiopod species.

2. Measurements of Plaesiomys subquadratus and related forms 


\section{BRACHIOPOD FAUNA OF SATURDAY MOUNTAIN FORMATION, SOUTHERN LEMHI RANGE, IDAHO}

By REUBEN J. ROSS, JR.

\begin{abstract}
Silicified brachiopods occur in the Saturday Mountain formation of the southern Lemhi Range, Idaho, in great numbers, but not in great variety. Nineteen species have been identified. Poor sorting by size or shape of shells at most localities suggests accumulation under quiet bottom condition. Austinella and the new genus Lordorthis are the most abundantly represented genera. Most of the fauna shows affinities with Late Ordovician species, but Middle Ordovician elements are present.
\end{abstract}

\section{INTRODUCTION}

\section{SCOPE OF THE INVESTIGATION}

The present study of brachiopods from the Saturday Mountain formation resulted from the geologic investigations of C. P. Ross in the southern Lemhi Range, Idaho. His early collections indicated that a well-preserved, silicified fauna might be obtained. In 1955 P.E. Cloud, Jr., MacKenzie Gordon, and I accompanied Ross in five days of rewarding collecting.

Several thousand brachiopod specimens have been dissolved from the enclosing dolomitic limestone, but only a small percentage of these were unbroken. The Saturday Mountain formation has been involved in much structural deformation with adverse effects on most of the enclosed shells.

Use of formic acid on small samples of the rock has yielded conodonts and specimens of the bryozoan Sceptropora facula Ulrich replaced by iron oxide, in addition to other silicified bryozoans and a few corals. Only the brachiopods are described here.

\section{ACKNOWLEDGMENTS}

The present work has been greatly assisted by loans of type specimens. C. O. Dunbar, Yale Peabody Museum, lent the types and topotypes of Zygospira jupiterensis Twenhofel and $Z$. aequivalvis Twenhofel; N. D. Newell, American Museum of Natural History, lent the types of Plaesiomys subquadratus (Hall) and Zygospira recurvirostris (Hall); C. F. Kilfoyle, New York State Museum, lent topotype material of $Z$. recurvirostris (Hall); and R. E. Sloan, University of Minnesota, lent topotype material of Austinella whit- fieldi (Winchell). Robert Morris gave critical advice on proper handling of stereophotography which was put into practice by F. B. Rowell. T. G. Lovering gave valuable advice on statistical problems.

\section{STEREOPHOTOGRAPHY OF THE SPECIMENS}

Stereophotographs presented in this paper were taken with an ordinary view camera of old vintage. To obtain paired photographs, each specimen was placed on a sliding base and moved between exposures so that the distance between images on the film was $50 \mathrm{~mm}$. This is a proper average distance for use with an ordinary $2 \times$ pocket stereoscope.

Vertical exaggeration is not the same for all the photographs, and it will differ with differences in interpupillary distance of each observer.

For an average interpupillary distance of $62 \mathrm{~mm}$ the present photographs will have approximate vertical exaggerations of 0.9 for $\times 1$, of .6 for $\times 2$, and of .75 for $\times 3$ magnifications, when viewed through a conventional pocket stereoscope.

\section{FOSSIL COLLECTING LOCALITIES}

Fossils on which this report is based were collected from about twenty localities on the west side of the southern end of the Lemhi Range. Because there is no land grid by which localities can be accurately designated, reference to approximate longitude and latitude is accompanied by brief topographic descriptions. A topographic map prepared for C. P. Ross is reproduced here (fig. 145) with the localities indicated.

Probably every locality listed from which I, personally, have collected is less than 75 feet stratigraphically above the base of the formation. These localities are D234 CO, D235 CO, D236 CO, D237 CO, D238 CO, and D240 CO. At some localities there is a thin quartzite layer within the formation according to C. P. Ross (written communication). If this is everywhere so, $I$ may have mistaken it for the top of the Kinnikinic quartzite. 


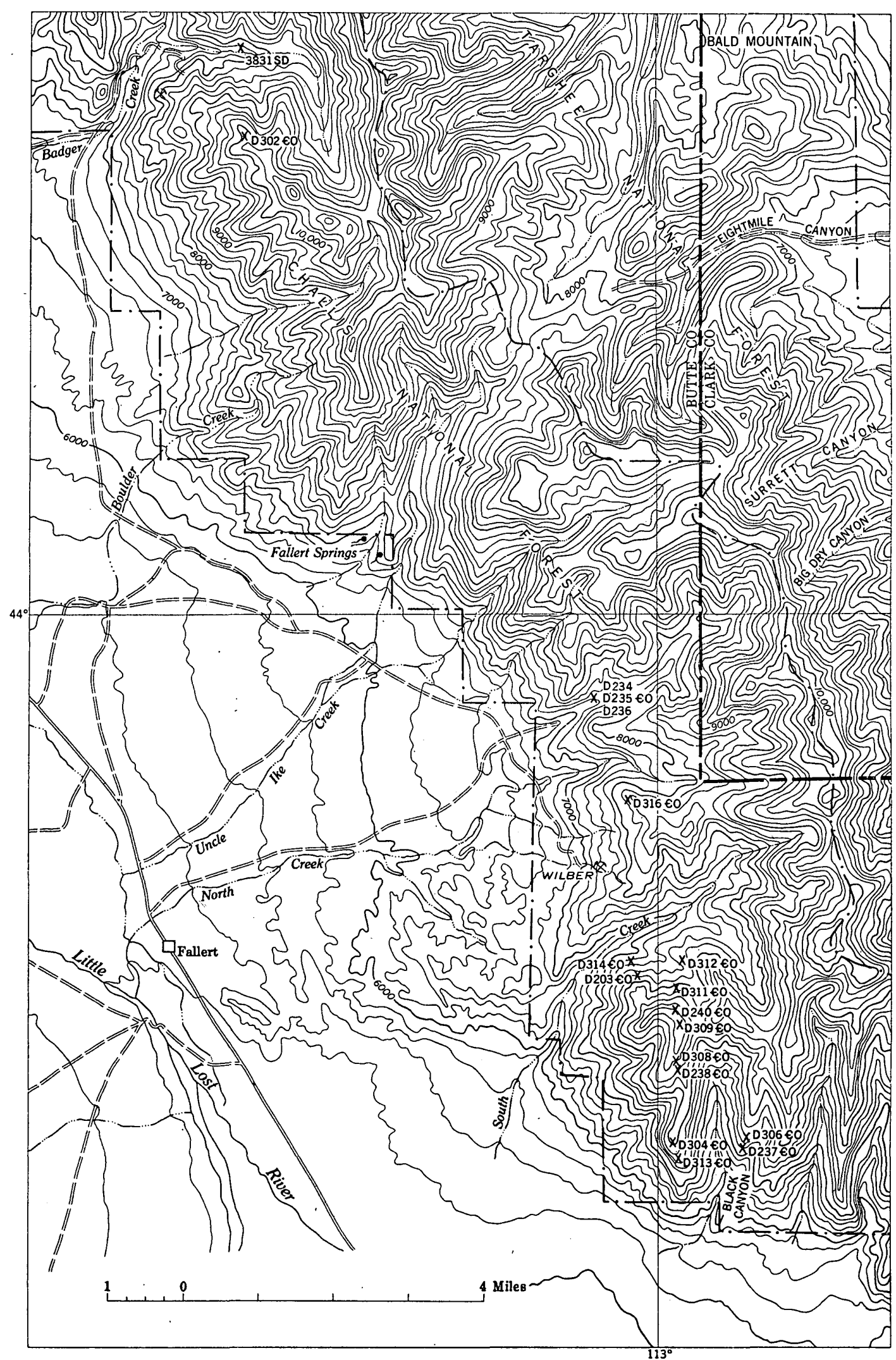

Frgurs 145. Fossil collecting localities in the Saturday Mountain formation, southern Lembl Range, Idaho. 
Usas locality D203 CO

D234 CO

D235 CO

$\mathrm{D236} \mathrm{CO}$

D237 CO

Co

D240 CO

D302 CO

D304 CO

D306 Co

D308 CO

D309 CO

D311 CO

D312 Co

D313 CO

D314 CO

D316 CO

3831 SD
Description

South of south fork of South Creek, elev 7,800 ft. N. $43^{\circ} 55^{\prime} 48^{\prime \prime}$, W. $113^{\circ} 00^{\prime} 26^{\prime \prime}$.

North side of North Creek Canyon, $150 \mathrm{ft}$ above valley floor and $150 \mathrm{ft}$ east of Kinnikinic contact. N. $43^{\circ} 59^{\prime} 01^{\prime \prime}$, W. $113^{\circ} 01^{\prime} 00^{\prime \prime}$.

North side of North Creek Canyon, $140 \mathrm{ft}$ above valley floor and $150 \mathrm{ft}$ east of Kinnikinic contact, elev 7,200 ft. N. $43^{\circ} 59^{\prime} 01^{\prime \prime}$, W. $113^{\circ} 01^{\prime} 00^{\prime \prime}$.

North side of North Creek Canyon, $135 \mathrm{ft}$ above valley floor and $150 \mathrm{ft}$ east of Kinnikinic contact, elev 7,200 ft. $N$. $43^{\circ} 59^{\prime} 01^{\prime \prime}$, W. $113^{\circ} 01^{\prime} 00^{\prime \prime}$.

East side of Black Canyon, elev 7,200 ft. N. $43^{\circ} 53^{\prime} 48.5^{\prime \prime}$, W. $112^{\circ} 58^{\prime} 40^{\prime \prime}$. D237a, $9 \mathrm{ft}$ above base of formation. D237b, 21 $\mathrm{ft}$ above base. D237c, $30 \mathrm{ft}$ above base.

West side of Black Canyon, elev 8,500 ft. N. $43^{\circ} 54^{\prime} 46^{\prime \prime}$, W. $112^{\circ} 59^{\prime} 43^{\prime \prime}$.

On ridge between Black Canyon and South Creek, just north of divide, elev $8,800 \mathrm{ft}$. N. $43^{\circ} 55^{\prime} 28^{\prime \prime}$, W. $112^{\circ} 59^{\prime} 42.5^{\prime \prime}$.

South of south fork of Badger Creek, elev 10,000 ft. N. $44^{\circ} 05^{\prime} 31^{\prime \prime}$, W. $113^{\circ} 06^{\prime} 39.5^{\prime \prime}$.

On ridge west of Black Canyon, elev 8,000 ft. N. $43^{\circ} 53^{\prime} 50^{\prime \prime}$, W. $112^{\circ} 59^{\prime} 45^{\prime \prime}$.

ast side of Black Canyon, elev 7,500 ft. N. $43^{\circ} 53^{\prime} 53.5^{\prime \prime}$, W. $112^{\circ} 58^{\prime} 38^{\prime \prime}$.

West side of Black Canyon, elev $8,600 \mathrm{ft}$. N. $43^{\circ} 54^{\prime} 49^{\prime \prime}$, W. $112^{\circ} 59^{\prime} 43^{\prime \prime}$.

On ridge $\mathrm{NW}$ of Black Canyon, elev 8,900 ft. N. $43^{\circ} 55^{\prime} 17^{\prime \prime}$, W. $112^{\circ} 59^{\prime} 46^{\prime \prime}$

Southwest side of south fork of South Creek, elev 8,100 ft. N. $43^{\circ} 55^{\prime} 39^{\prime \prime}$, W. $112^{\circ} 59^{\prime} 40.5^{\prime \prime}$.

Close to creek on north side of south fork of South Creek, elev 7,700 ft. N. $43^{\circ} 58^{\prime} 33^{\prime \prime}$, W. $112^{\circ} 59^{\prime} 42.5^{\prime \prime}$.

South of Black Canyon, elev 7,700 ft. N. $43^{\circ} 53^{\prime} 40^{\prime \prime}$, W. $112^{\circ} 59^{\prime} 40^{\prime \prime}$.

South of south fork of South Creek, elev 7,300 ft. N. $43^{\circ} 55^{\prime} 59^{\prime \prime}$, W. $113^{\circ} 00^{\prime} 30^{\prime \prime}$.

About halfway between North and South Creeks, elev 8,350 ft. N. $43^{\circ} 57^{\prime} 49.5^{\prime \prime}$, W. $113^{\circ} 00^{\prime} 26^{\prime \prime}$.

North side of south fork of Badger Creek, elev $7,800 \mathrm{ft}$. N. $44^{\circ} 06^{\prime} 28.5^{\prime \prime}$, W. $113^{\circ} 06^{\prime} 41.5^{\prime \prime}$. (May be erosion remnant of Laketown dolomite or equivalent strata)

DATING OF THE SATURDAY MOUNTAIN FORMATION BASED ON PREVIOUS EVIDENCE

The Saturday Mountain formation was named and described (C. P. Ross, 1934, p. 952-956; 1937, p. 18-22) for its exposures in the Bayhorse region, Idaho. In 1947 Ross (p. 1104-1105) noted its presence in the Borah Peak quadrangle. In both reports the formation was dated as Late Ordovician, and in the Bayhorse area it was correlated with the Fish. Haven dolomite and the upper part of the Bighorn dolomite.

In the Bayhorse quadrangle, Borah Peak quadrangle and southern end of the Lemhi Range the Saturday
Mountain formation overlies the Kinnikinic quartzite, which until 1947, was thought to be of Middle Ordovician age. Ross at that time (p. 1104) cited G. A. Cooper as the authority for correlating the quartzite with the Fernvale formation "of early Upper Ordovician age." This required that the Saturday Mountain be younger than the Fernvale.

None of the Receptaculites, Maclurites, or large cephalopods that characterize the Red River formation, the lower member of the Bighorn, and the Whitewood dolomite, have been reported from it-suggesting that the Saturday Mountain formation should not be correlated with these units. Correlation with the Hanson Creek formation of Nevada is not as firmly established as might be hoped.

Lithologically much of the Hanson Creek formation, particularly on Mount Hamilton (Pancake Summit quadrangle, Nevada), cannot be distinguished from the Fish Haven dolomite. The two are probably parts of a single unit of wide extent. If the Saturday Mountain is correlative with the Fish Haven dolomite, it should be equivalent to the Hanson Creek also.

The silicified brachiopods obtained on Mount Hamilton (Locality D283 CO) were too poorly preserved to be identified as to species. However, the dinorthids and dalmanellids that comprise most of the fauna are not identical with those of the Saturday Mountain formation, nor are they the same as those from the uppermost Bighorn dolomite. Unfortunately, preservation is so poor that only this negative evidence is available and I am unable to determine what fauna specimens from the Hanson Creek resemble most closely. Therefore, exact correlation of the Saturday Mountain formation with the Hanson Creek of central Nevada is not yet possible on the basis of brachiopods.

One collection from the Saturday Mountain strata of the Bayhorse region contained graptolites (Ross, C. P., 1934 , p. $954-955 ; 1937$, p. 21) which were identified by Ruedemann. The listed graptolites may be expected to indicate correlation with the Lower Caradoc; this is considerably older than the brachiopod and coral fauna seems to indicate. C. P. Ross (1937, p. 22) noted the discrepancy but so far as I know no explanation has ever been offered for it.

In the Bayhorse area the Saturday Mountain has been considered younger than the Ramshorn slate (Ross, C. P. 1937, p. 16-22), considered "Deepkill" in age, i. e. Arenig to Llanvirn and older than Caradoc. However, one collection from an isolated area of outcrop (T. 8 N., R. 18 E.) includes specimens "probably referable to Monograptus," an exclusively Silurian genus. According to C. P. Ross (1937, p. 17) lithologic similarity indicated that this outcrop should be mapped as Ramshorn slate, not as Silurian Trail Creek forma- 
tion. Therefore, the Ramshorn slate could range from Arenig to Silurian in age.

If so, the Ramshorn slate is equivalent in age and facies to the Phi Kappa formation of the Wood River district. The Saturday Mountain formation on the other hand would be equivalent in age only to a part of the Ramshorn slate and in facies would contrast strongly with it. The geographic distribution of Ramshorn and Saturday Mountain strata within the Bayhorse area (Ross, C. P., 1934, plate 1), their contrasting lithologies, but partly correlative ages indicate either that the two are examples of a peculiar facies change or that they have been placed in juxtaposition tectonically. Tectonic activity might easily explain the presence within the geographic bounds of the Saturday Mountain formation of shales of Caradoc age, derived from the Ramshorn slate.

Nolan, Merriam, and Williams (1956, p. 33) note the occurrence of graptolites in the Hanson Creek formation. This fauna has been identified and dated by Ruedemann (Merriam and Anderson, 1942, p. 1686; Ruedemann, 1947, p. 108) as correlative with the Polk Creek shale of Arkansas and the Sylvan shale of Oklahoma, both of which are supposedly of Ashgill age. This indicates that the Hanson Creek is younger than the graptolite-bearing beds of Caradoc age assigned by C. P. Ross (1937, p. 18-22) to the Saturday Mountain formation. There is evidence from locality $3831-$ SD (p. 245) that the Saturday Mountain formation as mapped by C. P. Ross (written communication, 1957) is locally of Silurian age or that a local remnant of Silurian strata rests between Ordovician and Devonian units. Therefore, the Ashgillian beds of the Hanson Creek may correlate with part of it.

In Nevada the Hanson Creek is locally in juxtaposition with correlative Ordovician rocks of the Vinini formation. These are graptolite-bearing shales of an entirely different facies thrust in from the west (Nolan, Merriam, and Williams, 1956, p. 34). In Idaho, though not in the southern Lemhi Range, similar black shales of the Phi Kappa formation are. in close proximity to the Saturday Mountain formation (Umpleby, Westgate, and Ross, 1930, p. 18-23, pl. 1). The age of the beds of the Phi Kappa seems to range from Llandeilo to Ashgill. Studies on graptolites from the Valmy and Vinini formations of Nevada lead me to conclude that it ranges from Arenig through Ashgill in age.

It therefore seems evident that the concept of a Western Ordovician facies should now be considered for Idaho, just as it has been accepted for Nevada. As stated above this concept might also clarify the interrelations of the Saturday Mountain and Ramshorn strata of the Bayhorse area. The eastern time equiva- lents of the Phi Kappa are the Kinnikinic quartzite and Saturday Mountain formation; its southern time and rock equivalents are the Vinini and Valmy formations.

\section{COMPOSITION AND SIGNIFICANCE OF THE BRACHIOPOD FAUNA}

\section{COMPOSITION OF THE FAUNA}

The brachiopod fauna of the Saturday Mountain formation in the southern Lemhi Range is little varied. Specimens are silicified and therefore can be obtained in abundance, but only 19 species have been collected (see table 1).

Distribution of these species by locality is shown in table 1. Because collections from many of the localities were merely small field samples, distribution cannot be considered entirely reliable. For example, the sample from locality D302 CO; submitted for identification late in 1955, contained a single specimen of Lepidocyclus. Additional collecting would probably yield other species at that locality.

\section{AGE OF THE FAUNA}

Most of the genera listed above are found both in Middle and Upper Ordovician rocks. Austinella occurs both in the Waynesville shale of the Richmond group and the Maquoketa shale. Until recently it was generally accepted as a Richmond index fossil. Sinclair $(1956$, p. 128) questioned the value of Austinella in this respect, suggesting that it may occur in beds of Trenton age. Flower (written communication, June $11,1956)$ is convinced of the Red River age of the Burnam limestone of Texas in which Austinella also is present (Barnes, Cloud, and Duncan, 1953, p. 1037). It is Flower's conviction (1952, p. 25-26) that the Red River formation is more likely to be of Trenton than of Richmond age, because many genera of Red River cephalopod associations "are appearing in strata of unquestionably late Trenton age." Flower (1952, p. 27) places emphasis on the cephalopods from the Terrebonne formation in the vicinity of Montreal. These forms he states are related to the Red River fauna, but the strata of the Terrebonne are considered by Clark $(1952$, p. 62,74$)$ to be of late Trenton age.

Lordorthis variabilis Ross $\mathrm{n}$. gen. and sp. bears a strong resemblance to Dolerorthis of Silurian age and may be fairly closely related to some Silurian species of Hesperorthis (pl. 54, fig. 26) (Whittard and Barker, 1950). Zygospira putilla adds a Silurian element to the fauna but $Z$. cf. $Z$. circularis Cooper and $Z$. cf. $Z$. lebanonensis Cooper are closer to forms of Middle Ordovician age. The specimens of Austinella compare very closely with topotype material of $A$. whitfieldi from the Maquoketa shale of Minnesota. The bryozoan 
TABLE 1.-Distribution of brachiopods and one coral species

\begin{tabular}{|c|c|c|c|c|c|c|c|c|c|c|c|c|c|c|c|c|c|}
\hline \multirow{2}{*}{ Species } & \multicolumn{17}{|c|}{ Locality } \\
\hline & D203 & D234 & D235 & D236 & D237 & D238 & D240 & D302 & D304 & D306 & D308 & D309 & D311 & D312 & D313 & D314 & D316 \\
\hline 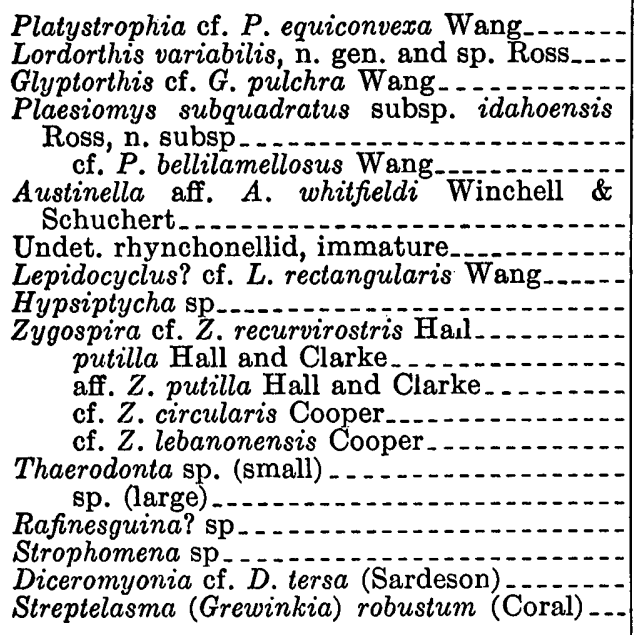 & 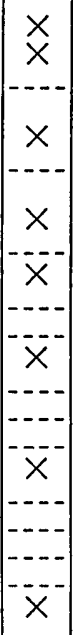 & 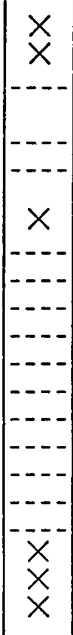 & \begin{tabular}{c}
$x$ \\
$X$ \\
\hdashline-- \\
\hdashline$X$ \\
\hdashline$x$
\end{tabular} & 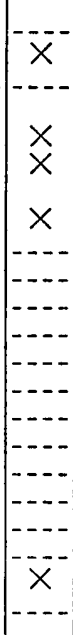 & \begin{tabular}{c}
$x$ \\
$x$ \\
$x$ \\
$x$ \\
$x$ \\
\hdashline$X$ \\
$X$ \\
$X$ \\
$X$ \\
\hdashline \\
\hdashline \\
\hdashline \\
\hdashline \\
\hdashline
\end{tabular} & 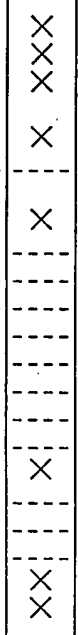 & \begin{tabular}{c}
$x$ \\
$x$ \\
$x$ \\
$x$ \\
\hdashline$x$ \\
$x$ \\
\hdashline$x$ \\
\hdashline$x$ \\
\hdashline$x$ \\
\hdashline$x$ \\
$x$ \\
$x$ \\
$x$ \\
$x$ \\
$x$ \\
\hdashline--
\end{tabular} & 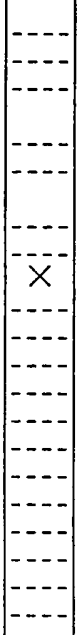 & 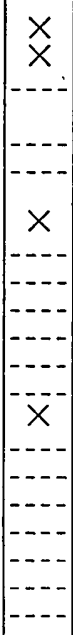 & 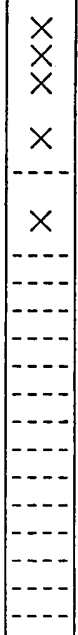 & 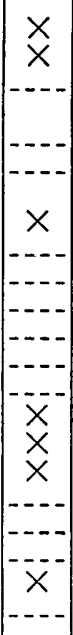 & 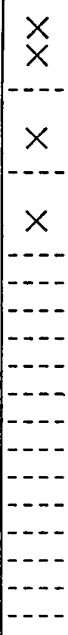 & 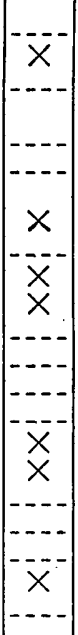 & 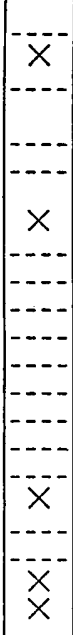 & 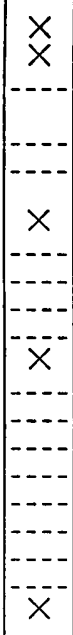 & 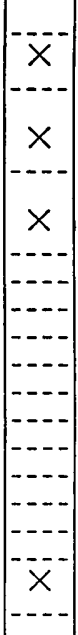 & 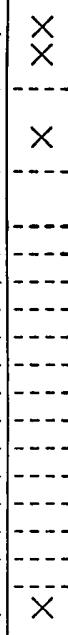 \\
\hline
\end{tabular}

Sceptropora facula Ulrich, important because it is known only from the Richmond, Maquoketa and Stony Mountain formations and from the correlative uppermost beds of the Bighorn dolomite, is present in some of the collections.

The previous Late Ordovician dating of the Saturday Mountain formation is not as clearly substantiated as might be desired.

If the Fernvale formation is truly of Late Ordovician age and if the brachiopod fauna of the Kinnikinic is indisputably correlative with that of the Fernvale, the overlying Saturday Mountain must be of Late Ordovician and(or) Silurian age. On Badger Creek, C. P. Ross (oral communication, February 24, 1958) collected Silurian fossils (USGS Loc 3831-SD) from talus which may have been derived from the topmost beds of the Saturday Mountain formation and(or) from a local remnant of Laketown dolomite.

North of Badger Creek, in the Bayhorse region (C. P. Ross, 1934, p. $954-955$; 1937, p. 21), graptolites that I consider to be of early Caradoc (Middle Ordovician) age have been reported from the Saturday Mountain formation. If these are not in Ramshorn slate tectonically mixed with the Saturday Mountain formation, the latter seems to have been deposited during Middle and Late Ordovician (and possibly some of Silurian) time.

The presently known brachiopod fauna is not clearly of Middle or Late Ordovician age. Fossils that suggest a Late Ordovician age are:

Sceptropora facula (bryozoan)

Platystrophia cf. P. equiconvexa Wang

467782-59- -2
Glyptorthis cf. G. pulchra Wang

Plaesiomys subquadratus idahoensis Ross n. subsp.

$P$. bellilamellosus Wang

Austinella aff. A. whitfieldi Winchell and Schuchert

Lepidocyclus甲 cf. L. rectangularis Wang

Thaerodonta sp.

Diceromyonia cf. D. tersa (Sardeson)

Six of these nine species compare closely with but are not necessarily identical to previously known Late Ordovician forms.

Three species of a single genus have Middle Ordovician affinities: $Z$ ygospira cf. $Z$. recurvirostris, $Z$. cf. $Z$. circularis, and $Z$. cf. $Z$. lebanonensis. Yet these are associated with a Silurian index fossil, Z. putilla.

Questions raised about the significance of Austinella have been mentioned above.

Comparison with known Late Ordovician brachiopod faunas of North America is hampered by the complete lack of monographic studies on any collections from the western United States.' Cooper (1956, p. 6) notes that Middle Ordovician strata in Nevada should receive additional attention although his own recent study (1956) is the only one on brachiopods of Middle Ordovician age west of the Black Hills.

At present it seems wise to state only that the brachiopod fauna described here has more Late than Middle Ordovician affinities, and that its exact correlatives cannot yet be determined.

\section{ECOLOGIC SIGNIFICANCE OF THE FAUNA}

The brachiopod shells seem to have been moved little by bottom currents or waves. The ocean bottom in this area may have been quiet. Evidence for this conclusion is given below. 
About the same number of brachial and pedicle valves occur in the collections, suggesting little sorting according to different hydrodynamic behaviour of the valves. There are more articulated shells than usual in similarly etched silicified deposits, indicating little movement by waves. Immature growth stages of several species are abundant; however they do not outnumber mature specimens, as might be expected if there had been no sorting whatsoever according to size.

Large shells of Lordorthis variabilis (pl. 54, fig. 13) generally have poorly preserved ribs. This might be interpreted as the result of abrasion. However, immature specimens of this species have ornamentation preserved in the finest detail (pl. 54, figs. 31, 36) and as shown by two of the illustrated specimens (pl. 54, figs. $1,9,13)$ ribbing seems to deteriorate at major growth lines. There is good evidence that poorness of ribbing is normal in this species after shells have reached lengths of $10-15 \mathrm{~mm}$.

Certain expectable elements of Middle and Late Ordovician faunas are missing or scarce; these include the large rhynchonellids, such as Lepidocyclus capax, and large strophomenids. Representatives of each of these are found but they are rare. The reason for their scarcity is not apparent.

\section{SYSTEMATIC DESCRIPTION OF THE BRACHIOPODS} Class ARTICULATA

Superfamily ORTHACEA

Family PLECTORTHIDAE Schuchert and Cooper, 1931

Subfamily PLATYSTROPHIINAE Schuchert, 1929

Genus Platystrophia King, 1850

Platystrophia cf. $P$. equiconvexa Wang

Plate 56, figures 1, 2, 5-8

This species is not well represented in the collections. All of the mature specimens are broken or deformed, and observations must be based on imperfect and immature specimens. These belong to the "low fold subgroup of the triplicate group" of McEwan (1920, p. $390)$.

The outline is subrectangular and hinge extremities are essentially right-angled; they may be slightly obtuse, or slightly acute. The dorsal valve has convex flanks. Pedicle flanks are equally convex on half the specimens at hand, and a little less so on the others. There are four costae on the fold and three in sinus, all of about the same size as those on the flanks. The largest specimen in the collections has 12 costae on the flanks and 1 or 2 additional incipient ribs in the postero-lateral corners. A similar number are present on one much smaller specimen. One small specimen has
10 costae on one flank and eight on the other. The fold is $4.7 \mathrm{~mm}$ wide and $3.6 \mathrm{~mm}$ high at the front of a valve $11.2 \mathrm{~mm}$ wide. The fold is a little more prominent than in $P$. equiconvexa (Wang, 1949, pl. 4B, fig. 4).

The small specimens of this species are easily confused with $P$. extensa McEwan in which the pedicle valve has the more convex flanks (McEwan, 1920, pl. 42, fig. 40). They also resemble $P$. elegantula var. triplicate McEwan which possesses distinctly obtuse postero-lateral angles (McEwan, 1920, pl. 43, fig. 48). I have discovered no practical way to distinguish immature specimens of the Saturday Mountain species from $P$. amoena $\mathrm{McEwan}$, but the adults are readily distinguished by the greater number of flank costae, larger size, and relatively higher fold. $P$. colbiensis Foerste is very similar in outline. McEwan (1920, p. 414) states that there are 9-11 costae on its flanks, but her illustrations (McEwan, 1920, pl. 44, figs. 8-11) and Foerste's (1910, p. 55-56, pl. 4, fig. 2) original description indicate that there are 8 or $9 . P$. colbiensis has a fold even lower than those of immature specimens of the Saturday Mountain species.

Since all of the species compared above are of Middle Ordovician age it is fortunate that collections were not limited to immature specimens by which erroneous dating could have been suggested.

Mature specimens closely resemble $P$. annieanna Foerste which, however, has concave flanks on the pedicle valve and a longer hinge line. $P$. clarksvillensis Foerste has a longer hinge line and fewer costae on the flanks. From $P$. equiconvexa Wang the specimens at hand differ in having a more prominent fold and deeper sulcus. The strong convexity of the pedicle valve is not a consistent feature, but the observed range of variation includes the holotype of $P$. equiconvexa (Wang, 1949, pl. 4B, figs. 3, 4, 5).

If better material were available it might be possible to determine whether the specimens belong to $P$. equiconvexa or to a new species.

Figured specimens: USNM 133259-133261

Localities: D203 CO, D234 CO, D235. CO, D237 CO, D238 CO, D240 CO, D304 CO, D306 CO, D308 CO, D309 CO, D313 CO, D316 CO.

\section{Family HESPERORTHIDAE Cooper, 1956}

Subfamily HESPERORTHINAE Schuchert and Cooper, 1931 Genus Lordorthis Ross, new genus

Essentially this genus includes resupinate species that would otherwise be assigned to Hesperorthis. At present it is monotypic.

In immature stages the shells are planoconvex and some immature specimens of the type species indicate that the brachial valve may be slightly concave. Mature brachial valves are convex anteriorly. Pedicle 
valves in immature stages are hemipyramidal but become anteriorly concave or flattened. A chilidium like that of Hesperorthis may be present, but is preserved probably only rarely. The delthyrium is partly closed by an apical plate or pseudodeltidium also comparable to that of Hesperorthis. The pedicle cardinal area is apsacline and wider than long. In adult specimens the angle between sides of the delthyrium is approximately 60 degrees; in immature specimens it may be considerably less.

The brachiophores are bladelike and the cardinal process simple. The definition of the median septum of the brachial valve is variable in the type species. In the pedicle valve the muscle field is typically that of Hesperorthis.

Type species.-Lordorthis variabilis Ross, n. sp.

Discussion.-Lordorthis closely resembles Boreadorthis (Öpik, 1934, p. 184-186) and Dolerorthis; both of these genera have convex brachial and flattened pedicle valves. The resemblance to Boreadorthis is the closer because that genus also possesses Hesperorthis-like cardinalia, a chilidium and pseudodeltidium. Neither Boreadorthis nor Dolerorthis passes through a planoconvex or concavo-convex stage of growth and as a result their brachial valves possess continuously convex lateral profiles. In Lordorthis on the other hand, brachial valves are initially flat or concave (plate 54, figs. $6,20,22,36$ ) ; the mature valves, though convex, always have an initial concave profile close to the interarea (plate 54, fig. 2).

The stout brachiophores of Dolerorthis and its lack of chilidium and deltidium also serve to distinguish that genus from Lordorthis.

Until its shells are over $6.0 \mathrm{~mm}$ long Lordorthis variabilis, the type species, can be unquestionably classified with Hesperorthis. Thereafter the shells become resupinate.

\section{Lordorthis variabilis Ross, n. sp.}

Plate 54, figures 1, 2, 4-6, 8-11, 13-17, 19-25, 27-28, 31-32, 35, 36

This species is the most abundant of all brachiopods in the Saturday Mountain formation of the Lemhi Range. Over 100 specimens are at hand and these show considerable variation, especially in outline of the shells.

Exterior--The outline is variable, being subsemicircular, subsemiellipitical or subrectangular. The brachial valve is gently convex with a faint median sulcus that fades out anteriorly. The pedicle valve is gently convex at the umbo, flattening anteriorly; in old specimens it is slightly resupinate toward the margin. The dorsal area is anacline and short, while the pedicle interarea is apsacline, plane to very slightly curved, about a third as long as wide.

A few specimens of brachial valves show thin uplifted edges on the inside of the notothyrium (pl. 54, fig. 21). These and a single small specimen with an arched plate in place indicate that there was a delicate chilidium with the general shape of those in Hesperorthis (compare pl. 54, fig. 35 with Schuchert and Cooper, 1932, pl. 4, figs. 17, 18, 29). The pseudodeltidium is essentially as in Hesperorthis; a few specimens have an arched rather than flat plate (pl. 54, figs. 14, 16) and a very few have the pseudodeltidium isolated by conjoining adventitious material added to the sides of the delthyrium. In these last the pseudodeltidium seems to have been built forward beneath the adventitious material (pl. 54, figs. 23, 24).

Specimens in which the edges of the delthyrium are raised in the same manner as the edges of the notothyria mentioned above are fairly numerous; these originally led me to surmise that an arched deltidium must have been present. Addition of material along the edges of the delthyrium is common in the Hesperorthinae (Schuchert and Cooper, 1932, p. 85).

The ribbing is more highly variable than other features of the shells. There is a definite tendency for external ribbing to become obscure after shells have reached a length of $15 \mathrm{~mm}$. Some are paucicostate, others multicostate. Counts made at an arbitrary median length of $18 \mathrm{~mm}$ from the umbo of the pedicle valve indicate that simple costae average 7 in $10 \mathrm{~mm}$ of width, and may be expected statistically to number as low as 4 and as high as 10. For shells in which smaller ribs are intercalated between the costae the total count at $18 \mathrm{~mm}$ from the pedicle beak may be expected to range as high as 14 in $10 \mathrm{~mm}$ of width.

Interior of the ventral valve.-The description of the pedicle interior follows almost exactly that given by Schuchert and Cooper (1932, p. 88) for the genus Dolerorthis, but most of the differences which they considered interspecific are here clearly variations among individuals of the one species. The distinctness with which the median ridge and two pallial trunks are developed is highly variable; this cannot be attributed entirely to mode of preservation. (Compare pl. 54, figs. $4,14,19,24$.)

Interior of the brachial valve.-The brachial interior is essentially that of Hesperorthis. Not one of the large brachial valves shows the muscle scars well enough to differentiate the anterior from the posterior adductors, a condition illustrated by Öpik (1934, fig. 43) for Boreadorthis; this leads me to consider the possibility that the posterior scars are the larger and that the anterior pair may be so small that they are insig- 
nificant-a condition approached by Dolerorthis rustica osiliensis (see Schuchert and Cooper, 1932, pl. 5, fig. 23). One immature brachial valve does show a faint transverse ridge between anterior and posterior pairs so that they are almost equal in size; the posterior pair is only slightly larger. In this immature characteristic, as in several others, Lordorthis variabilis strongly resembles Hesperorthis.

The most obvious variation in this species is found in the ratio between the lengths and widths of valves; this is particularly obvious in pedicle valves and is illustrated by specimens in plate 54 , figures $4,8,13$, and 19. Because there are variants between the extremes of subrectangular and subsemicircular shells they all obviously belong to the same species.

Shells which are subrectangular tend to have fine costae intercalated between the coarse primary costae (see pl. 54, fig. 4). Those which are subsemicircular have few if any intercalated parvicostae (pl. 54, fig. 13). The difference is probably a reflection of the difference in peripheral distance around shells of two shapes, there being room for more ribs on a rectangle than on a semicircle of comparable size. The specimen illustrated in plate 54 , figure 13 , belongs in the subsemicircular group. Fortunately it shows growth lines, and it will be noted that when the median length was about $17 \mathrm{~mm}$ this was a subrectangular shell.

Immature characteristics.-Immature specimens of this species have several features in common with Hesperorthis. Small specimens (pl. 54, figs. 22, 25, 28, 32 ) have nearly flat brachial valves and strong simple costae, and some of them I previously identified as Hesperorthis in preliminary study of the collections. Still smaller specimens (pl. 54, figs. 27, 31, 26) show the manner in which many of these seemingly simple ribs are intercalated and also show the strongly lamellose nature of the surface in the immature stages.

The smallest specimen found (pl. 54, figs. 6, 10) is a brachial valve. It possesses the brachiophores and cardinal process characteristic of the genus even at this early stage and can be readily distinguished from similarly small specimens of Austinella (pl. 55, figs. 2, 7).

Holotype: USNM 133227

Paratypes: USNM 133228-133237

Localities: D203 CO, D234 CO, D235 CO, D236 CO, D237 CO, D238 CO, D240 CO, D304 CO, D306 CO, D308 CO, D309 CO, D311 CO, D312 CO, D313 $\mathrm{CO}, \mathrm{D} 316 \mathrm{CO}$.

Discussion.-Whittard and Barker (1950, p. 564-565, pl. VI, figs. 8, 9) described Hesperorthis onniensis from the Upper Valentian of Shropshire. A latex cast of the type and only known specimen is illustrated here (pl. 54, fig. 26). This Lower Silurian species closely resembles the present one in outline and convexity of the bracial valve. The brachiophores are not quite so long, however. Because the exterior of the British valve is unknown, no further comparison can be made. Williams (1951, p. 89) has criticized Whittard and Barker for assigning specimens of this type to Hesperorthis rather than to Dolerorthis and has redescribed and illustrated Dolerorthis plicata Sowerby (Williams, 1951 , p. 88-89, pl. 3, figs. 1-3) from the Llandovery; this species differs from the Saturday Mountain specimens in its lack of deltidial plate, character of its ribbing, and bluntness of brachiophores.

Cooper (1956, p. 298-299, pl. 36E, figs. 32-39) has described Orthambonites brachiophorus from the Effna-Rich Valley and Boutetort formations in Virginia (Porterfield Stage of Cooper, 1956, p. 8, chart 1). This species is strikingly similar to $L$. variabilis in several respects: the type of cardinal process and brachiophores, fine concentric ornamentation, convex brachial valve with a shallow sulcus disappearing toward the anterior margin, pedicle muscle pattern and pallial markings.

Cooper $(1956$, p. 294,299$)$ notes that his species does not conform to the strict concept of Othambonites and that it does resemble Hesperorthis in cardinalia and outline. However, he states that no evidence for a pseudodeltidium has been found, a fact which militates against assignment of $O$. brachiophorus to Hesperorthis.

As more information is gathered on forms similar both to 0 . brachiophorus and to Lordorthis variabitis a closer relationship than is now indicated may become evident. This possibility suggests that species of Lordorthis may be discovered in Middle as well as in Upper Ordovician strata.

\section{Subfamily GIYPTORTHINAE Schuchert and Cooper, 1931 Genus Glyptorthis Foerste, 1914 \\ Glyptorthis cf. G. pulchra Wang}

Plate 54, figures 39, 40; Plate 56, figures 18-20, 25, 26

Glyptorthis pulchra Wang, 1949, Geol. Soc. America Mem. 42, p. 4 , pl. 1E, figs. 1-10

This species is represented by seven specimens. The material is too poor to make accurate comparisons with other species but good enough to be sure that it does not belong to any of the species described by Cooper (1956, p. 361-383) from Middle Ordovician rocks. It most closely resembles $G$. pulchra Wang.

It is a fairly large species, two pedicle valves being $20 \mathrm{~mm}$ wide and $15 \mathrm{~mm}$ long. The anterior outline is bilobed, particularly in pedicle valves. Convexity of both brachial and pedicle valves is about equal. The brachial one possesses an angular sulcus of almost uni- 
form depth; at the front this contains 6 costellae on one specimen and 9 on another. The surface is covered by 51-55 costellae; in $5 \mathrm{~mm}$ at the front there are 6-7. Concentric lamellae are spaced 10 in $5 \mathrm{~mm}$. A single strong costella forms the crest of the pedicle fold.

In the pedicle valve the muscle field extends forward about half the length of the valve and has a raised front edge.

Figured specimens: USNM 133244, 133264, 133265, 133266.

Localities: D237 CO, D238 CO, D240 CO, D306 CO.

Discussion -A complete individual was obtained from locality D238 CO which is obviously more mature than the other specimens (pl. 56, figs. 18, 25, 26). Unfortunately lateral compression has deformed the two valves, accentuating the brachial sulcus at the anterior margin and creating a false sulcus at the front of the pedicle valve. Another equally large specimen from locality D240 CO shows that the pedicle fold extends to the margin.

Family DINORTHIDAE Schuchert and Cooper, 1931

Genus Plaesiomys Hall and Clarke, 1892

Plaesiomys subquadratus (Hall)

Plate 55, figures 1, 6, 12, 14, 15, 18, 19, 23

Orthis subquadrata Hall, 1847, Paleontology of New York, v. I, p. 126, pl. 32A, figs. 1a-o.

Hall's (1847) original type specimens were never well illustrated. Three of them are here shown in stereoscopic view so that comparisons may be made more accurately.

Figured specimens: AMNH 913/6.

Locality: "Hudson River Group," Cincinnati, Ohio.

Plaesiomys subquadratus subspecies idahoensis Ross, n. subsp.

Plate 54, figures $29,30,33,34,37,38,41,42$; plate 55 , figures $22,26,27,30,31$

Shell outline is subrectangular to subelliptical and about three-fourths as long as wide. The brachial valve is moderately convex with a shallow sulcus. The pedicle valve is almost flat with a very low narrow fold, that is carinate near the umbo. The hinge line is straight, the width at hinge being about three-fourths the greatest width of the shell. Cardinal angles are rounded and/or obtuse. Ornamentation is multicostate, averaging 14 costae in a space of $10 \mathrm{~mm}$ at a distance of 15 $\mathrm{mm}$ from the beak. The costae may bifurcate 2 to 3 times and are rounded with narrow interspaces.

The pedicle interarea is short and apsacline; the brachial interarea is short, and orthocline to slightly apsacline. The cardinal process with its crenulated myophore projects beyond the plane of the interarea.

Type specimen : USNM 133239
Figured specimens: USNM 133240-133243

Localities: D203 CO, D235 CO, D236 CO, D237 CO, D238 CO, D240 CO, D306 CO, D309 CO, D314 CO, D316 CO.

Discussion.-Features which have been used to distinguish the species of Plaesiomys in the past are relative length and width of valves, width at the hinge line relative to the total width, definition of sulci and folds, and character of the ribbing. For instance, $P$. iphigenia. (Billings) and $P$. meedsi Winchell and Schuchert are distinguished from other species on the basis of their possession of a pedicle rather than a brachial sulcus.

$P$. subquadratus as described by previous authors is highly variable in relative length, width, and hinge width, as well as in the spacing of costellae. Of the previously described species of Plaesiomys the majority of the specimens from the Saturday Mountain formation compare most closely with $P$. subquadratus. The original type specimens of that species are here figured photographically for the first time (pl. 55, figs. 1, 6, 12, $14,15,18,19,23)$. On the average, the Idaho specimens are smaller in size but this might be the result of environment. Outline and convexity of the valves are proportionately very nearly the same. There are significant differences between the two; however, these may not be evident when comparing single specimens.

A statistical analysis of $P$. subquadratus was based on the three type specimens illustrated here plus 20 specimens for which Shaler (1876, Table IX) tabulated measurements. The necessary initial assumption was made that Shaler's sample represented a single species.

Scatter diagrams of several ratios were made for $P$. subquadratus and for the Saturday Mountain specimens (figs. 146-154). Raw data for these diagrams are given in table 2. Invariably these diagrams show much wider limits of variation for $P$. subquadratus than for the Idaho material, and the latter when plotted on the same diagram will fall within the limits of variation of $P$. subquadratus (as an example, see fig. 146).

However, when the regression lines, computed separately for the type and for the materials from the Saturday Mountain are plotted they do not coincide and several differences indicated are thought to be significant.

As an indicator of outline the length and width were plotted (figs. 147-150) and the resulting graphs compared for brachial and pedicle valves. Figures 147 and 148 show that the slope of the regression line for both samples of brachial valves is essentially the same but that these differ in position of the $y$ intercept. By itself this might mean little if the same were not the case in a comparison of the pedicle valves (figs. 149 and 150). 


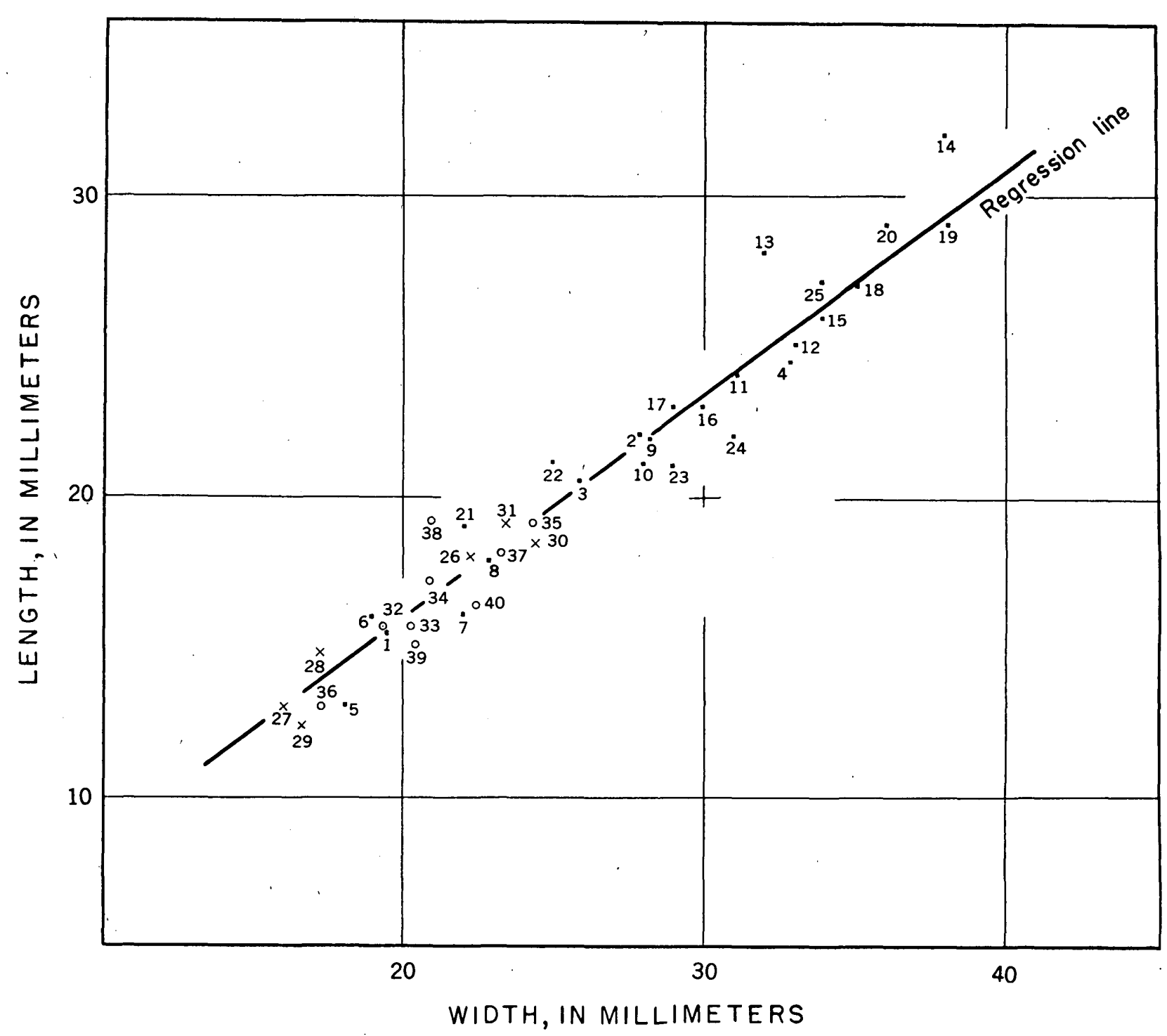

Fiaure 146. Plaesiomys subquadratus and comparable species. Scatter diagram of length: width, making no separation of brachial and pedicle valves. Regression line computed on 3 of Hall's type specimens (1847) and 20 of Shaler's (1876, Table IX) specimens. See table 2.

There is good correlation in both these cases between length and width. This is wholly expected, for one observes empirically that the shells become wider as they grow longer. For $P$. subquidratus the brachial valves tend to follow the following formula: Length = 0.82 Width -0.76 . For the Idaho sample the formula is: Length $=0.83$ Width -1.33 . The difference between the two is in the constant, which indicates that for any given width brachial valves from Idaho will be $0.56 \mathrm{~mm}(1.33-0.76)$ shorter than those of typical $P$. subquadratus. This difference could never be detected on 1 or 2 specimens and is so small that it may not be reliable when large samples are measured.

The comparison of pedicle valves (figs. 149 and 150) indicates that the two lots tend to differ by $0.71 \mathrm{~mm}$ in length, the Idaho specimens being the shorter for any given width. Again, this difference cannot be ascertained with 1 or 2 specimens and would require large samples for comparison.

The width at the hinge line has been used to differentiate the variety occidentalis by Ladd $(1929$, p. $402-$ 403 , pl. 5, figs. 7-9). This variety is supposed to be much narrower at the hinge than other forms of Plaesiomys. Ladd $(1929$, p. 403$)$ states that the hinge is little more than half as wide as the shell's total width. Figure 151 is a plot of the hinge width against the total width of valve. Computations of regression line and standard error were limited to $P$. subquadratus (points 1-24). Here we find that variety occidentalis (point 26 ) is well within limits of variation for the species and has no more narrow a hinge than one of Hall's original type specimens (pl. 55, figs. 12, 14) (point 3). The 


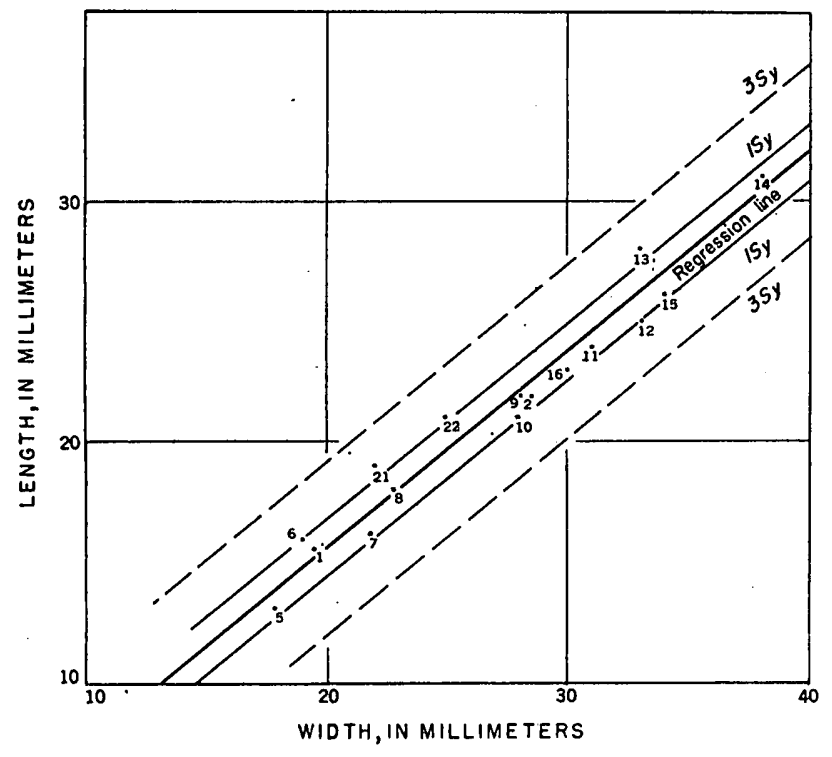

Floure 147. Scatter diagram of length: width in brachlal valves of Plaesiomys subguadratus. Regression line $(Y=0.82 \mathrm{X}-0.76)$ based on 2 of Hall's types and 14 of Bhaler's specimens (see table 2). Standard error (Sy) $=1.2$.

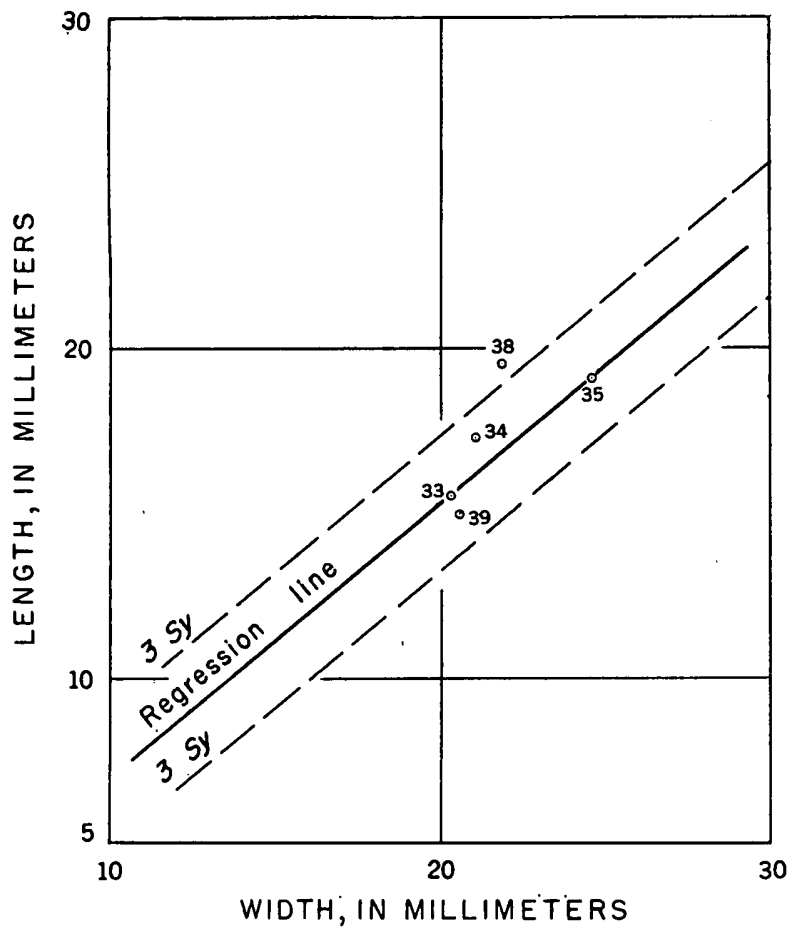

Fioure 148. Scatter dfagram of length: width in brachial valves of Plaesiomys subquadratus subsp. idahoensis. Regression line: $\mathrm{Y}=0.83 \mathrm{X}-1.33$. Standard error $(\mathrm{Sy})=0.68$. For list of points see table 2. Computation excludes point 38 .

graph (fig. 151) also shows that the specimen identified by Wang (1949, p. 5-6, pl. 2D) as var. occidentalis (fig. 151, point 30) has a wider hinge than is average for the species and therefore cannot belong to Ladd's variety. $P$. bellilamellosus Wang (point 31 ) is so close to variety occidentalis in all respects that $I$ suspect that they are one and the same.

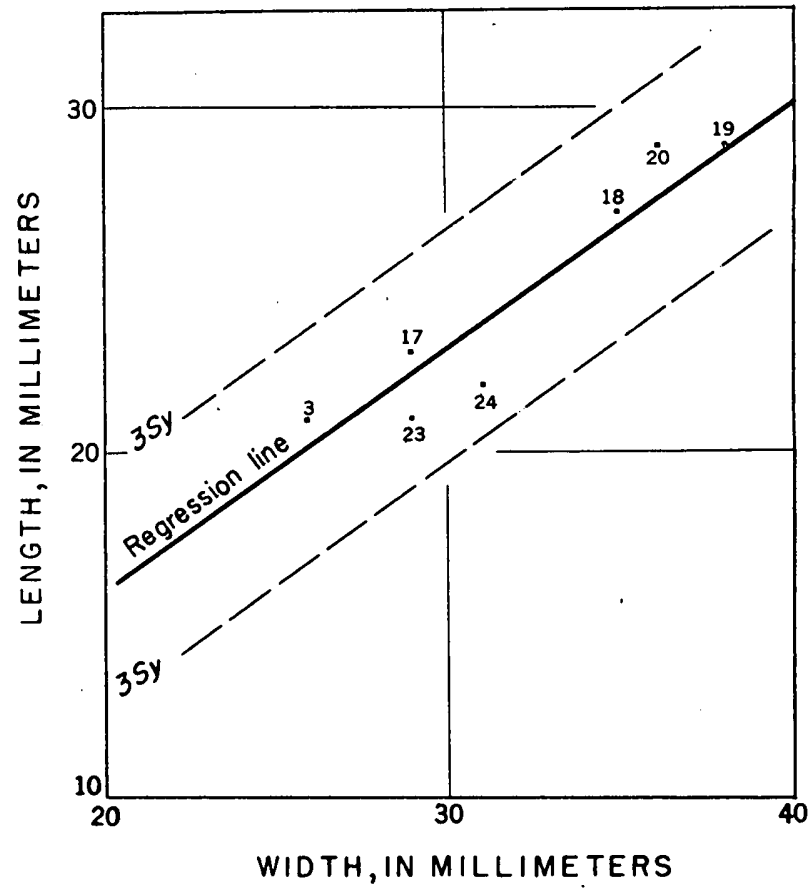

Fioure 149. Scatter diagram of length: width in pedicle valves of Plaesiomys subquadratus. Regression line: $\mathrm{Y}=0.72 \mathrm{X}+1.6$. Standard error $(\mathrm{Sy})=1.12$. Computation based on 1 of Hall's types and 6 of Shaler's specimens (see table 2).

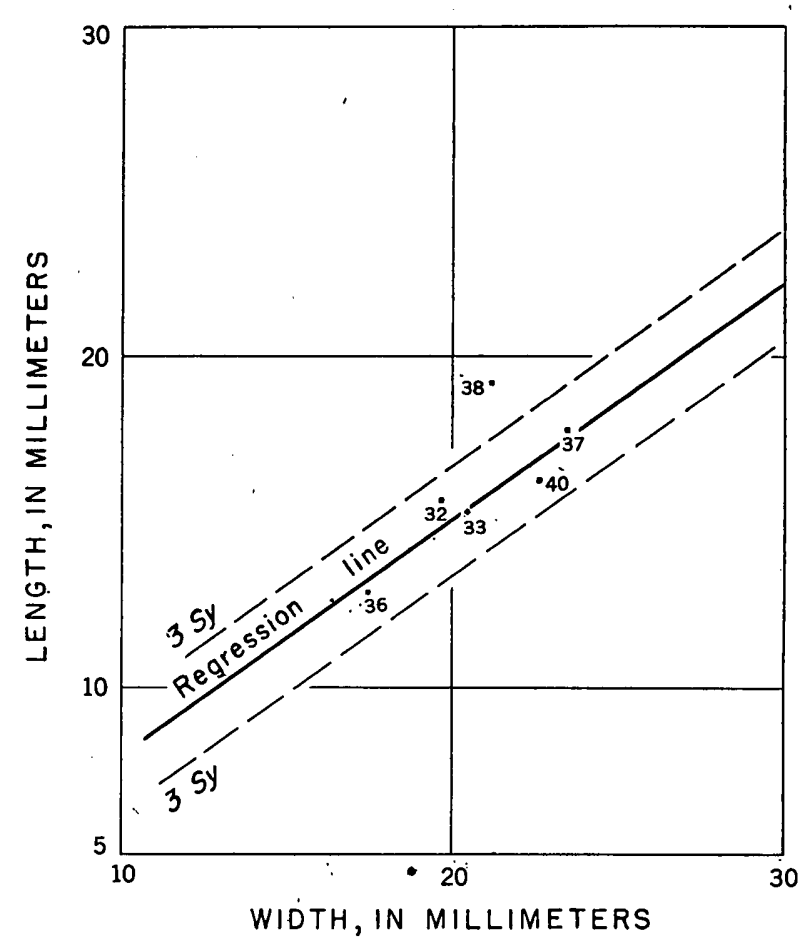

Fioure 150. Scatter diagram of length: width in pedicle valves of $P$. subquadratus subsp. tdahoensis. Regression line: $\mathrm{Y}=0.71 \mathrm{X}+0.89$. Standard error $(\mathrm{Sg})=0.57$. See table 2 for specimens. Computation excludes number 38.

The graph for the same proportion in the Idaho specimens (fig. 152) shows a different slope for the regression line. For specimens with widths under $30 \mathrm{~mm}$ the Saturday Mountain specimens will be wider at the hinge 


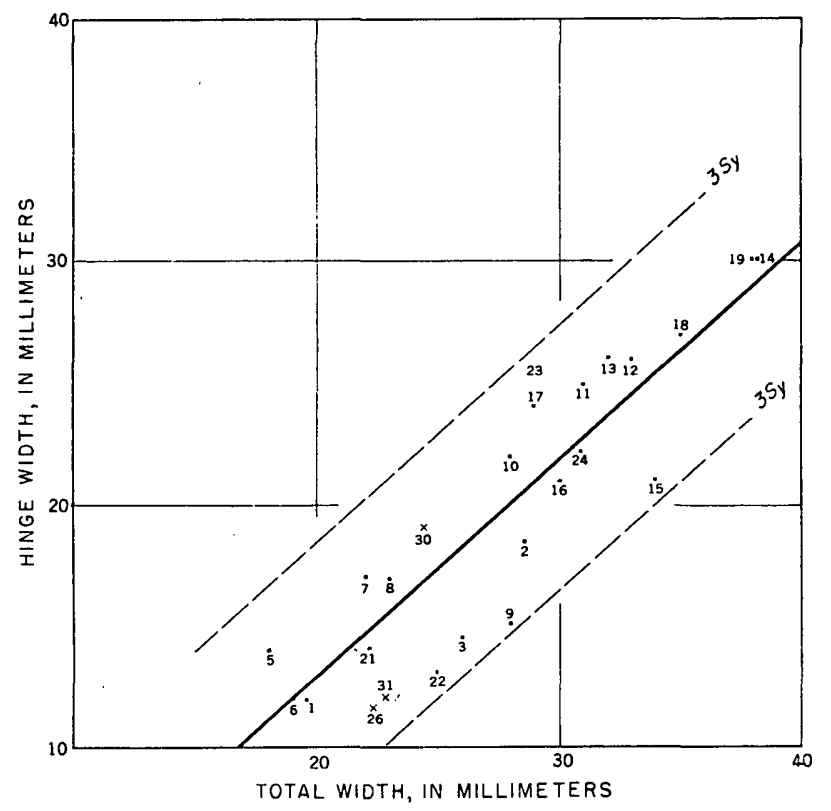

FinURE 151. Scatter diagram of hinge width: total width in Plaesiomys subquadratus. Regression line: $Y=0.898 X-4.99$. Standard error $(\mathrm{Sy})=1.83$. Computation based on three of Hall's types and 20 of Shaler's specimens (see table 2).

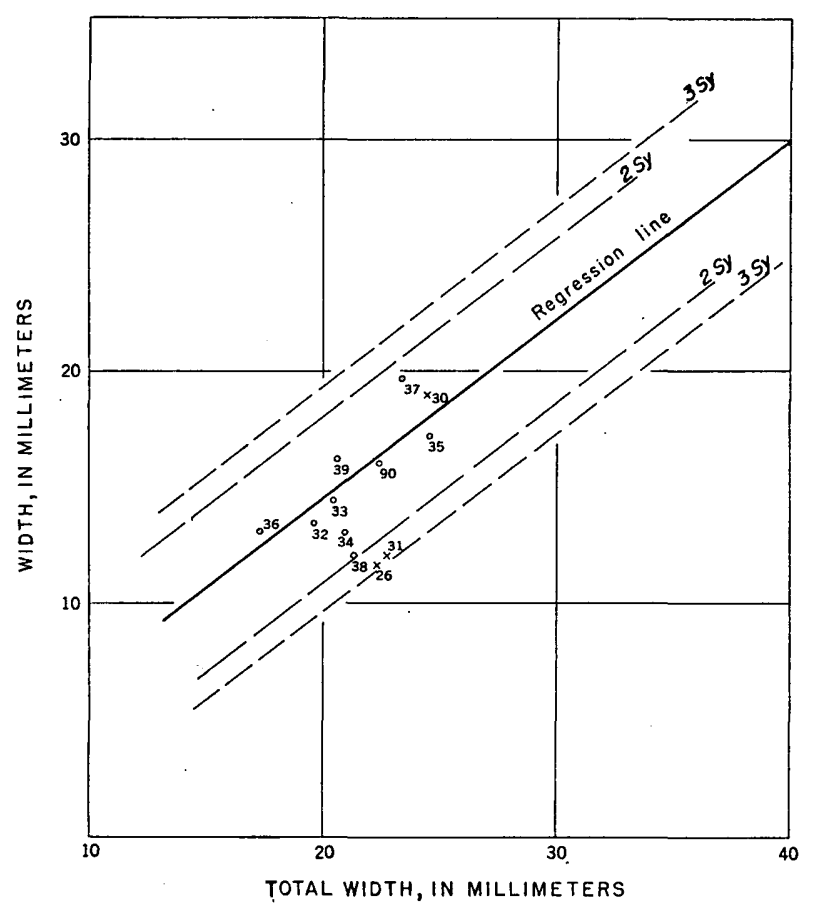

Figure 152. Scatter diagram of hinge width: total width in $P$. subquadratus subsp. idahoensis. Regression line: $\mathrm{Y}=0.77 \mathrm{X}^{d}-0.93$. Standard error $(\mathrm{Sy})=1.8$. (See table 2 for specimens.)

than will those of $P$. subquadratus. Again, this is not a difference that can be told from individual specimens, unless they are so narrow at the hinge as to fall below the expectable limits of variation of the Saturday Mountain forms.

Finally there are plotted in figures 153 and 154, the number of costellae in a space of $10 \mathrm{~mm}$ at the front

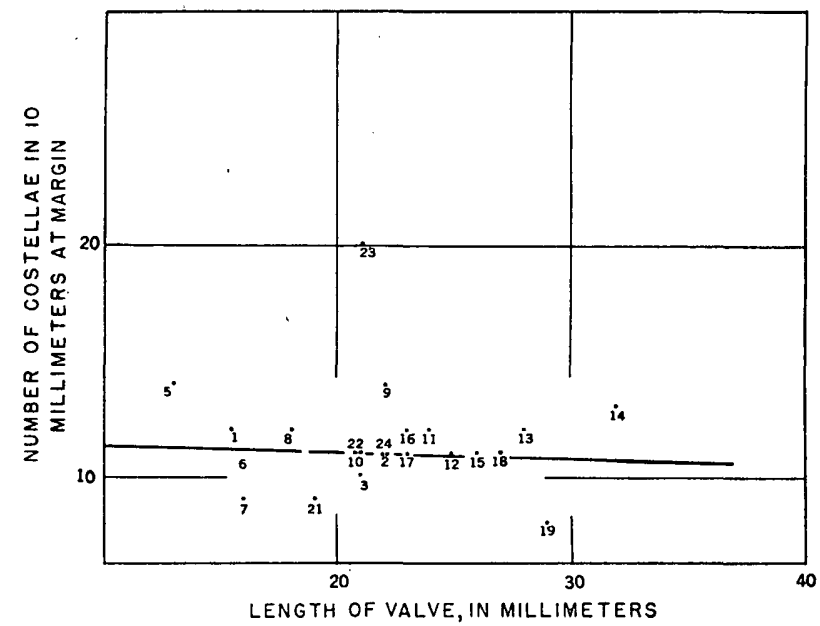

FIGURE 153. Scatter diagram of number of costellae in $10 \mathrm{~mm}$ at front of valve: length of valve in $\mathrm{mm}$ for Plaesiomys subquadratus. Regression line: $\mathrm{Y}=11.68-0.02 \mathrm{X}$. Computation based on three of Hall's types and nineteen of Shaler's specimens (specimen 23 excluded from computation) (see table 2 for list of specimens).

of the valve against the length of the valve. These graphs show at once that there is practically no correlation between the size of the valve and the spacing of costellae. I have obtained similar results by taking the number of costellae in $10 \mathrm{~mm}$ at a set distance of 15 $\mathrm{mm}$ from the beak. The two populations can obviously be differentiated on the basis of rib spacing. In $P$. subquadratus there is an average of 11-12 costellae in 10 $\mathrm{mm}$ at the front of the shell, while in the Saturday Mountain forms the average is $14-15$. There is obvious overlapping between the two tendencies.

The specimens of Plaesiomys from the Saturday Mountain formation are very similar to $P$. subquadratus. They differ in being smaller in size, in having finer costellation, in being very slightly shorter, and in being a little wider at the hinge than $P$. sub. quadratus. The differences do not seem to be great enough to warrant placing the Idaho specimens in a

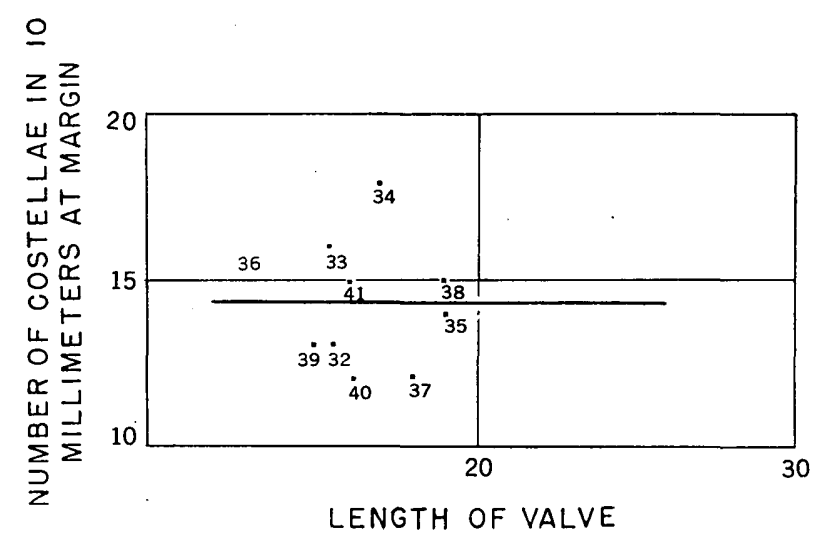

Fiaure 154. Scatter diagram of number of costallae in $10 \mathrm{~mm}$ at front of valve: length of valve in $\mathrm{mm}$ for $P$. subquadratus subsp. idahoensis. Regression line: $\mathrm{Y}=14.57$ $0.01 \mathrm{X}$. (See table 2 for list of specimens.) 
TABLE 2.-Measurements of specimens of Plaesiomys subquadratus and related forms

[Numbers correspond to points on graphs (flgs. 146-154). Specimens are designated brachlal (B), pedicle (P), or complete (C)]

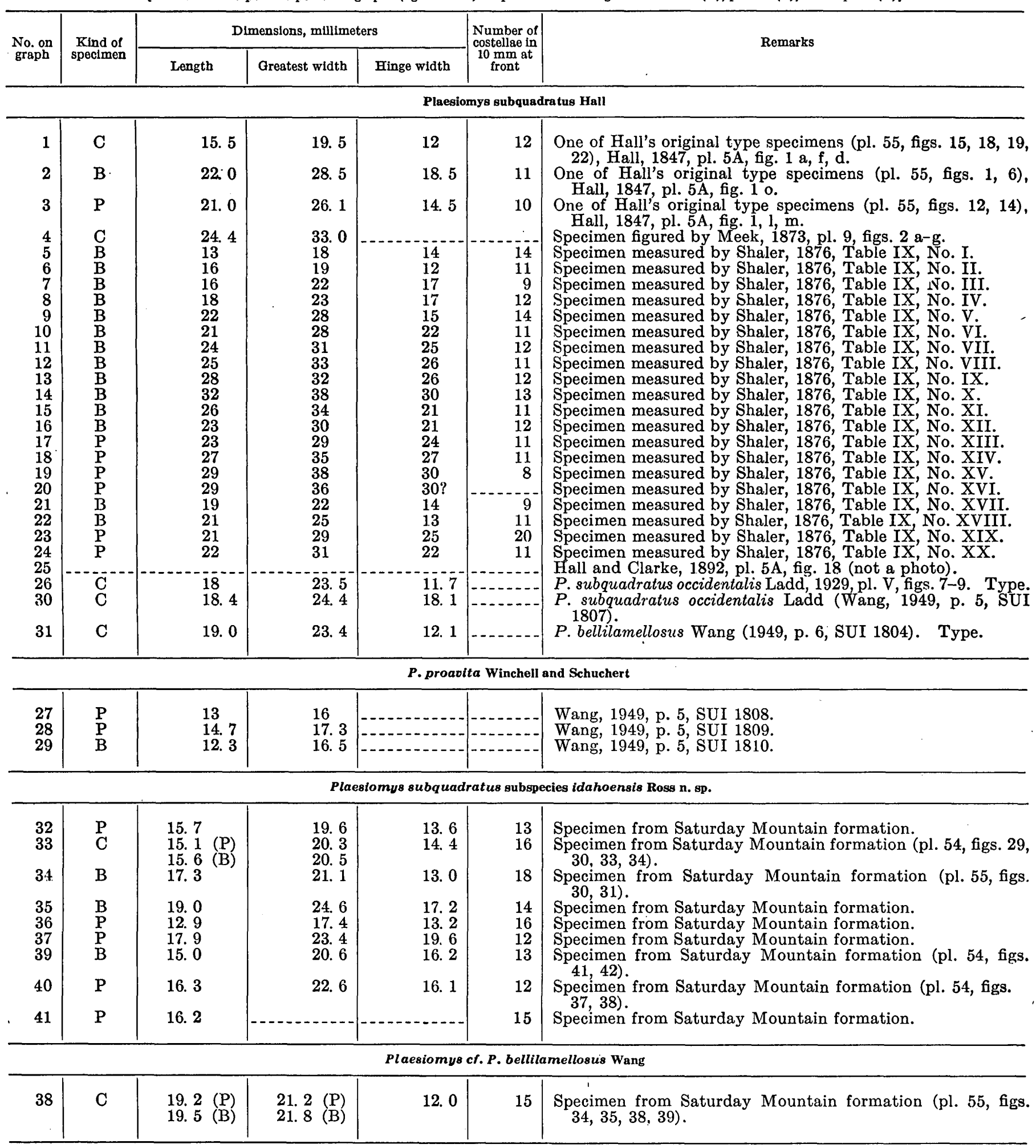


separate species, but I do believe they should be considered a subspecies.

Whether this is a geographic or a stratigraphic subspecies is open to question. There is ample reason to believe that it could be geographic, since the Lemhi Range is about 2,000 miles west of Cincinnati, Ohio.

Throughout the statistical computations on subspecies idahoensis one specimen (point 38 on the graphs; pl. 55, figs. $34,35,38,39$ ) was omitted. The belief that it belongs to a separate species seems justified by most of the statistical data. A second specimen (pl. 55, figs. 30, 31 , and point 34 on the graphs) conforms very nicely with the rest except in regard to fineness of costellae in the central part of the shell. Conformation of the margin suggests that this may be a pathologic specimen.

\section{Plaesiomys aff. P. bellilamellosus Wang}

Plate 55, figures 34, 35, 38, 39

Plaesiomys bellilamellosus Wang, 1949, p. 6, pl. 2C, figs. 1-7.

The outline is subcircular. There is a shallow, narrow sulcus on the brachial valve. The postero-lateral flanks are slightly concave in posterior profile. The pedicle valve lacks a pronounced fold and is flattened anteriorly. The surface is multicostate, there being 17 costae in $10 \mathrm{~mm}$ at $10 \mathrm{~mm}$ from umbo but 15 costae at $15 \mathrm{~mm}$ from umbo.

The brachial interarea is short, narrow, and orthocline to slightly apsacline. The cardinal process with its crenulated myophore projects beyond the plane of the interarea. The notothyrium is wide, and the median septum short and weak. The pedicle interarea is short, apsacline, and slightly curved.

\begin{tabular}{|c|c|c|c|}
\hline & Length & Width & $\begin{array}{l}\text { Hinge } \\
\text { woidth }\end{array}$ \\
\hline Figured specimen (complete) & 19.5 & 21.2 & 12.0 \\
\hline Brachial valve-1- & 17.1 & 18.1 & 11.7 \\
\hline
\end{tabular}

Discussion.-This species is represented by 1 complete specimen and 1 brachial valve in the present collections, an inadequate sample on which to base comparisons. These are readily differentiated from all other specimens of Plaesiomys by the subcircular outline and narrow hinge. The closest relative seems to be $P$. bellilamellosus Wang. The range of outline or of hinge width is not determinable from Wang's description. Compared with the holotype the present specimens are not quite as wide relative to length and the hinges are slightly wider relative to the total width of the shell. Convexity is about equal, but ribbing is a little finer than that of $P$. bellilamellosus at a distance of $15 \mathrm{~mm}$ from the umbo. On figures 146-154 the single complete specimen is plotted as point 38 . Wang's type of $P$. bellilamellosus is point 31 .

$P$. bellitamellosus may prove synonymous with $P$. subquadratus var. occidentalis. Wang states that it differs in its subcircular to subquadrate outline, but this is precisely the outline required by the narrow hinge of variety occidentalis. The specimen identified by Wang as variety occidentalis (Wang, 1949, pl. 2D, figs. 1-5) compares very closely in outline and relative hinge width with $P$. subquadratus, but not with variety occidentalis.

\section{Genus Austinella Foerste, 1909}

This genus was originally given rather informal designation as a subgenus of Plectorthis by Foerste $(1909$, p. 224). He gave no clear description, merely stating that it was typified by Orthis kankakensis McChesney and included $O$. whitfieldi Winchell. Although this statement established $A$. kankakensis as the nominal type species, later Foerste $(1912$, p. 130) erroneously designated $A$. scovillei Miller as genotype.

According to Cooper (1944, p. 298) the genus possesses undivided costae, actually too stringent a restriction and one not borne out by Cooper's figures (1944, pl. 112, figs. 1, 2). Wang's illustrations (1949, pl. 2, A, B) show that both $A$. kankakensis and $A$. whitfieldi have bifurcating and (or) intercalated costae. Foerste (1912, pl. 8, fig. 8) shows that A. scovillei has few costae with almost no tendency to bifurcate or intercalate except close to the margin.

Foerste $(1912$, p. 131) differentiated $A$. scovillei from $A$. kanteakensis and $A$. whitfieldi (which he believed synonymous) because it had approximately 40 rather than 60-70 costae. Winchell and Schuchert (1895, p. 438) used precisely the same criterion to differentiate A. whitfieldi from $A$. kankakensis. But they placed equal weight on the supposed fact that the former had a much shorter hinge line than the latter. This interpretation is supported by Hall and Clarke (1892, pl. 5, figs. 24,26 ) and their illustrations may have been the basis for Winchell's and Schuchert's differentiation.

Schuchert and Cooper (1932, pl. 9, figs. 16, 19) illustrated a specimen as $A$. whitfieldi that has the proportions and ribbing of $A$. kankakensis. Wang (1949, p. 8, pl. 2 A, B, figs. 1-5) illustrated the more transverse of two species as $A$. whitfieldi, but stated (p. 9) that $A$. kankakensis has more numerous third generation costae. He expressed the opinion that outline is not diagnostic between the two species.

The great variation in ribbing and in outline of the specimens from the Saturday Mountain formation suggests that neither of these can be relied on indiscriminately. 
Austinella aff. A. Whitfeldi Winchell and schuchert

Plate 55, figures 2-5, 7-11, 13, 16, 17, 20, 21, 24, 25, 28, 29, 32, $33,36,37$

Outline subelliptical, hinge narrower than greatest width. Pedicle more convex than brachial valve. Some specimens markedly wider than long (pl. 55, fig. 20), others longer than wide (pl. 55, fig. 28) with all gradations between.

Costation yaries between two extremes. One is simple with bifurcations limited to the area near the cardinal extremities (pl. 55, fig. 20) ; the other has many bifurcations and intercalations (pl. 55, figs. 11,24). Between these are integrading specimens in which most bifurcation is at the sides. Many specimens have a very fine raised line in the interspace between each pair of costae (pl. 55, figs. 4, 9, 11, 36). Growth lines are strong and numerous on some specimens and lacking on others. A few have regularly spaced pits on the costae (pl. 55, figs. 11, 17, 36). These are similar to those of Plectorthis punctata Cooper (1956, pl. 84F).

The pedicle interior possesses the usual muscle scar for the genus with a straight raised front edge. Adjustor scars are well developed on the sides of stout receding dental plates and extend in front of the plates on the floor of the valve. The diductor scars may have sharp angles at the antero-lateral corners from each of which a double pallial trunk runs antero-laterally (pl. 55, figs. 21, 25). A few well-preserved specimens show a diamond pattern on the floor of the valve outside the muscle scars (pl. 55, figs. 21, 25).

The brachial valves show great variation in the shape of the cardinal process; some are thin with hardly any myophore (pl. 55, fig. 16) but others have a knoblike myophore, crenulated posteriorly (pl. 55, fig. 3). All gradations exist between these extremes. The quadripartite adductor scars are variously developed; in some specimens there are strong radiating ridges in the posterior pair but in others the ridges are faint or lacking.

Figured specimens: USNM 133246-133256

Localities: D203 CO, D234 CO, D235 CO, D236 CO, D237 CO, D238 CO, D240 CO, D304 CO, D306 CO, D308 CO, D309 CO, D311 CO, D312 CO, D313 CO, D314 CO.

Discussion.-The largest collection of this species comes from locality D240 CO. Unfortunately these specimens cannot make up in quantity what they lack in quality. All are rather coarsely silicified and almost all have a thin coating of claylike material pressed upon them. This may account for the fact that fewer of the specimens from this locality show the fine raised line between costae than do those from some of the other localities. It may also explain why few of the figured specimens from locality D240 CO seem to have pits on the costae. Actually they do, but the pits are barely discernable.

Locality D240 CO may be at a different stratigraphic level from the others. This cannot be ascertained until more detailed mapping of the area is undertaken, but a different level is not indicated by the rest of the fauna.

Like the collections of other species from this formation those of Austinella suggest that some of the common criteria for distinguishing species are of little practical value.

These features may be of interspecies significance:

1. Simple vs. bifurcating or intercalated ribbing.

2. Presence vs. absence of pits on ribs.

3. Strong myophore vs. thin myophore.

4. Transverse vs. elongate outline.

5. Absence vs. presence of a fine costella between each pair of costae.

These are the most striking differences among specimens in the Saturday Mountain collections. Using them I have attempted to sort specimens into groups. Examination of the few specimens figured here will give some idea of the nearly chaotic results. Separations made on one basis fail when others are taken into consideration. The specimens at hand probably represent a single variable population.

One example seems to illustrate the point. Three of the figured specimens, here called $\mathrm{A}, \mathrm{B}$, and $\mathrm{C}$, have a fine costella between costae; these are specimens in plate 55 , figures $9,11,17$. Of these, $A$ (fig. 9 ) is a brachial valve of the elongate variety, $B$ and $C$ (figs. $11,17)$ belong to a transverse variety. All three have comparable adductor scars. $A$ and $B$ (figs. 8,10 ) have small myophores, $C$ (fig. 16) has almost none. (Another specimen, not figured, from the same locality as $C$ has the same ribbing and outline but has a large myophore like that in plate 55, figure 3.) $A$ and $B$ (figs. 9, 11) have bifurcating costae, $C$ (fig. 17) does not. $A$ (fig. 9) has no evident pits on costae, $C$ (fig. 17) definitely does, and they can be made out on the imperfectly preserved surface of $B$ (fig. 11).

From this small fraction of the entire sample it is clear that the size of the myophore is not significant in distinguishing species in this case. Outline of the shells is not consistent with the type of ribbing. This last agrees with Wang's (1949, p. 8-9) conclusion that A. whitfieldi and $A$. kankakensis cannot be differentiated on the basis of shape. Sixteen specimens from the type locality of $A$. whitfieldi, 1 mile east of Spring Valley, Minn., were furnished by Professor Robert E. Sloan of the University of Minnesota. In that sample there is no correlation whatsoever between width at 
the hinge and the number of costae; 1 specimen is wide hinged with 60 costae, fitting Winchell's and Schuchert's (1895, p. 438) concept of A. kankakensis. About seven could be classed as $A$. whitfieldi and the rest are intermediate. The specimen illustrated by Wang (1949, pl. 2A, figs. 1-5) as $A$. whitfieldi probably should be considered in the intermediate category.

Like the Saturday Mountain specimens those from Minnesota show regularly spaced pits on the costae wherever preservation permits.

Wang $(1949$, p. 8) states that the costae of $A$. whitfieldi are "strong, subrounded, separated by narrow and deep interspaces." The topotype material shows that this is true only if one is observing a pedicle valve; the brachial valves have narrower costae with wider interspaces. In specimens of the $A$. kankakensis type the costae are narrowly rounded on both valves and the interspaces are of the same width as the costae.

A few of the specimens from Spring Valley show a trace of a fine costellae between costae; it is definitely not present in all specimens, but seems to be more common in the paucicostate individuals.

Ignorance of the full range of features of other species renders difficult, if not impossible, a comparison between them and the Saturday Mountain specimens.

In outline, profile, and size the average Saturday Mountain specimens are very similar to Austinella cooperi Roy from Frobisher Bay. However, specimens of that species in the United States National Museum have simple costae without bifurcation or intercalation.

All of the Saturday Mountain specimens are too coarsely ribbed for $A$. kankakensis as illustrated by other authors. Ribbing is too coarse for $A$. whitfieldi as illustrated by Wang (1949, pl. $2 A$ ) but on many specimens it compares favorably with illustrations by Winchell and Schuchert (1895, pl. 33, figs. 10, 13). Shape of the shells conforms more closely to that of $A$. whitfieldi as figured by Winchell and Schuchert than with those of specimens illustrated by Schuchert and Cooper (1932, pl. 9, figs. 16, 19) or by Wang $(1949$, pl. $2 A)$. Some specimens are very closely comparable to A. scovizlei as illustrated by Foerste (1912, pl. 8, figs. $8 \mathrm{a}-\mathrm{c})$. The more elongate, more narrowly hinged specimens bear a striking resemblance to the original figures of A. scovillei (Miller, 1882, pl. 1, figs. 5, 5a, 5b). According to Miller (1882, p. 40) the costae of that species increase by bifurcation, not by intercalation, and its pedicle valve is nearly flat. 'These two considerations seem to distinguish it from most of the Saturday Mountain forms.

It is obvious that some selected specimens from the present collections could be identified as $A$. whitfieldi and others as $A$. scovillei. The evident variation between specimens suggests that these two may be varieties or subspecies of one species. When compared with material in the U. S. National Museum specimens from Idaho are in general closer to those labelled $A$. scovillei than to $A$. whitfieldi or $A$. kanteakensis.

The specimen illustrated in figures 16 and 17 of plate 55 can be distinguished from $A$. delicata Wang $(1949$, pl. 1F) only by the pits on the costae. It possesses the same crowding of costae in the postero-lateral corners that Wang used as a criterion to distinguish his species from $A$. scovillei. It also has a thin cardinal process. This last is by no means a specific criterion; I believe the crowding of costae has been overweighted by Wang.

The pits on costae are true punctae in the youthful stages of growth. The small perforations are arranged in roughly concentric rows paralleling the margin. The row closest to the margin still opens into the inside of the shell but those closer to the umbo are sealed internally by shell material. Most of the older, thicker shells show no pits at all, the inner ends having been sealed and the outsides of the shells abraded.

Superfamily RHYNCHONELLACEA

Undetermined rhynchonellid(?) species

Plate 56, flgures 29, 30

Two immature specimens of a rhynchonellid(?) brachiopod are present in the collections. These are very neat little shells, moderately convex for a rhynchonellid. The brachial valve is nearly circular in outline. The greatest width of the pedicle valve is well forward, giving the shell a "tear-drop" form. There are 4 costae of equal size on the low brachial fold and 4 on each flank. The pair of costae adjacent to the fold are the largest. The surface is smooth, not lamellose.

It is not possible to tell from the two specimens whether small size is a constant feature or merely a sign of immaturity. Because no adult specimens were found no attempt is made to identify or name the species.

Figured specimens: USNM 133271

Localities: D237b CO, D240 CO.

\section{Superfamily SPIRIFERACEA \\ Genus ZYGOSPIRA Hall, 1862}

Zygospira is represented by numerous specimens in the present collections. All specimens are small, only three out of 80 exceeding $5 \mathrm{~mm}$ in length. The variety of form is somewhat surprising. A few can be assigned to $Z$. recurvirostris, a Middle Ordovician species, a few to $Z$. putilla, a Silurian species. If they were larger most of the specimens might pass for $Z$. aequivalvis 
Twenhofel or $Z$. kentuckiensis Nettleroth, supposedly late Ordovician species. A somewhat similar assemblage was found in a collection made by $\mathrm{E}$. $\mathrm{O}$. Ulrich from "Kimmswick, Pratt's quarry, $3 / 4$ mile south of Elsberry, Mo." (loc. $258 \mathrm{~g}$ ), but it lacks the true $Z$. putilla and the $Z$. cf. $Z$. circularis of the Idaho collections.

If material in the U. S. National Museum is typical one may observe from it that most Late Ordovician Zygospiras are large and coarse-ribbed, whereas Middle Ordovician species are small and fine-ribbed. In these respects, the Idaho specimens resemble most closely Middle Ordovician species.

Zygospira cf. $Z$. recurvirostris Hall

Plate 54, figures $3,7,12,18$

Three of about 80 specimens of Zygospira from Locality D240 CO can be assigned to this species; examples are present in other collections of the Saturday Mountain formation.

Because the type specimen of Hall's species (Hall, 1847 , p. 140, pl. 33, figs. 5a-d) has never been adequately figured, photographs of it are included here (pl. 56, figs. $3,4,9,10)$. This and two topotype specimens from the New York State Museum show that the median costa of the brachial valve and the median interspace of the pedicle valve are wider than the others, a fact not mentioned in any previous description $I$ have been able to find and illustrated only by Cooper (1956, pl. $142 \mathrm{H})$. In this species the flanks of the pedicle valve are flat or very slightly convex. In all the other forms found in the strata of the Saturday Mountain formation the pedicle flanks are concave. In the past, specimens from the so-called Trenton of Kentucky and states other than New York have been identified as $Z$. recurvirostris despite concavity of pedicle flanks and possession of bifurcating costae; several of these have been reexamined by Cooper (1956, p. 669-674).

Figured specimens: USNM 133238

Localities: D237b CO, D240 CO.

Zygospira putilla Hall and Clarke

Plate 56, flgures 11, 12

Zygospira putilla Hall and Clarke, 1895, Nat. History N. Y., Paleontology, v. 8, pt. 2, p. 365-366, pl. 83, figs. 29, 30.

Only two specimens have been found and both are in poor condition. They closely resemble Hall's and Clarke's figures. Z jupiterensis Twenhofel (1927, p. 215 , pl. 19, figs. 13-15) probably belongs to this species or is very closely related.

Figured specimen : USNM 133262

Localities: D203 CO, D313 CO.

Discussion.-Savage (1917, p. 130) reassigned this species to Atrypa on the basis of specimens from the
Silurian Edgewood limestone, but gave no reason and I find no evidence in the present collections that excludes it from Zygospira.

Comparison with specimens in the U. S. National Museum from the Edgewood limestone shows that the present material very closely resembles it in all but size. The two Idaho specimens are very much smaller.

Zygospira aff. Z. putilla Hall and Clarke

Plate 56, figures 16,17

About eight percent of the specimens of Zygospira in the Saturday Mountain collections resemble $Z$. $p u$ tilla in outline and profile, but none have the bifurcating or implanted costae which characterize that species. These specimens have about 15 costae of which 5 are within a very shallow brachial sulcus; the median rib is larger than the others, but not as large as the same rib in Z. putilla.

Savage (1917, p. 130) noted that many specimens of Z. putilla in the Edgewood limestone of Silurian age have simple rather than bifurcating costae. In a collection made by Ulrich (Ioc. 258g), labelled "Kimmswick *** one-half mile south of Elsberry, Mo.", there are five specimens of Zygospira. Two of these are almost indistinguishable from the Saturday Mountain specimens of this type.

Figured specimens: USNM 133263.

Localities: D237 CO, D240 CO.

Discussion.-These specimens are not to be confused with specimens identified as $Z$. putilla (pl. 56, figs. 11, 12) from Locality D203 CO.

\section{Zygospira cf. Z. circularis Cooper \\ Plate 56, figures 21-24, 27, 28}

Zygospira circularis Cooper, 1956, Smithsonian Misc. Coll., v. 127 , p. 670 , pl. $141 C$, figs. $18-21$; pl. $142 B$, figs. $6-10 ;$ pl. $142 D$, fig. 16.

Sixteen percent of the specimens of Zygospira from locality D240 CO are of a type similar to this species. In outline the Idaho specimens agree almost perfectly, but in profile they are a little more compressed, with more distinctly concave pedicle flanks. There are an average of 24 costae on the Saturday Mountain forms and only 22 (Cooper, 1956, p. 670) on those from Tennessee. The western specimens seem to be slightly smaller than those from the east.

Figured specimens: USNM 133267-133268.

Localities: D235 CO, D237 CO, D240 CO, D304 CO, D308 CO.

Discussion.-The specimens from Idaho also bear a resemblance to $Z$. resupinata Wang, from which they differ in possession of rounded rather than angular costae and much weaker sulcus and fold. 
This species contributes a Middle rather than Late Ordovician element to the fauna. $Z$. circularis is described from the Carters limestone of Tennessee, which Cooper (1956, Chart 1) considers older than the Trenton.

\section{Zygospira cf. Z. lebanonensis Cooper}

Plate 56, figures 31, 32, 35, 36, 37, 38, 41, 42

Zygospira lebanonensis Cooper, 1956, Smithsonian Misc. Coll., v. 127, p. 671-672, pl. 142C, figs. 11-15.

Most of the specimens of Zygospira fall into this category. The outline is subcircular to subpentagonal. The profile is compressed. The brachial sulcus is broad, ill-defined, and seems to include 5 costae, of which the center 1 is the largest. The flanks of the pedicle valve are concave. Ribbing is fairly coarse. The average number of ribs is 18 , but the number may range from 14 to 22 . The ribbing is simple, there being only 1 aberrant specimen on which 1 rib bifurcates.

Figured specimens: USNM 133269, 133270

Localities: D235 CO, D237 CO, D240 CO, D308 CO, D311 CO.

Discussion.-These specimens differ from typical $Z$. lebanonensis only in possessing a median rib a little larger than the others and having 14-22 costae instead of 18-23. The close resemblance suggests correlation with the Lebanon limestone of Tennessee, the Camp Nelson limestone of Kentucky, and the Barnhart formation of Cooper (1956, p. 116) of Missouri.

Specimens similar to this, but much larger, have been collected from the Reedsville shale in western Virginia and from the so-called Trenton(?) near Harrogate, Tennessee. They resemble $Z$. kentuckiensis Nettleroth (as figured by Hall and Clarke, 1895, pl. 54, fig. 15) except in size and similarly compare closely with $Z$. aequivalvis Twenhofel, of which a topotype is figured here (pl. 56, figs. 13, 14, 15).

\section{Superfamily STROPHOMENACEA \\ Genus Thaerodonta}

Plate 55, figures $40-43$

One and possibly two species of this genus are present in the Saturday Mountain formation. The second of these is known from a dozen specimens only one of which shows the critical hinge. The first is represented by three poorly preserved valves. The specimens are figured as a matter of record, but with such inadequate material no attempt is made to identify them to species.

Figured specimens: USNM 133257, 133258.

Localities: D203 CO, D237 CO, D238 CO, D240 CO, D308 CO, D311 CO, D312 CO.
Superfamily DATMANELLACEA

Genus Diceromyonia Wang 1949

Diceromyonia cf. D. tersa (Sardeson)

Plate 56, figures 33, 34, 39, 40, 43, 44

Orthis tersa Sardeson, 1892, Bull. Minn. Acad. Nat. Sci., v. 3, p. 331-332, pl. 5, figs. 11-13.

Resserella tersa (Sardeson), Cooper, 1944, in Shimer and Shrock, Index fossils of North America, p. 353, pl. 138, figs. $19,20$.

Diceromyonia tersa (Sardeson), Wang, 1949, Geol. Soc. America Mem. 42, p. 36, pl. $12 B$.

The present specimens are all poorly silicified. They have the transversely elliptical outline and narrow hinge which characterizes the species, but the brachial valve is a little more convex than might be expected. Growth lines are lacking on almost all specimens.

Figured specimens: USNM 133272, 133273, 133376

Localities: D234 CO, D235 CO, D236 CO, D238 CO, D240 CO, D308 CO, D311 CO, D312 CO, D314 CO.

\section{REFERENCES CITED}

Barnes, V. E., Cloud, P. E., Jr., and Duncan, H., 1953, Upper Ordovician of central Texas: Am. Assoc. Petroleum Geologists Bull., v. 37, p. 1030-1043.

Bassler, R. S., 1911, The early Paleozoic Bryozoa of the Baltic Provinces: U. S. Natl. Mus. Bull. 77, 382 p., 13 pls.

Clark, T. H., 1952, Montreal area, Laval and Lachine map areas : Quebec Dept. Mines, Geol. Rept. 46, 159 p.

Cloud, P. E., Jr., 1948, Assemblages of diminutive brachiopods and their paleoecological significance: Jour. Sedimentary Petrology, v. 18, pp. 56-60.

Cooper, G. A., 1944, Brachiopoda in Shimer and Shrock, Index fossils of North America, p. 277-365, pls. 105-143.

1956, Chazyan and related brachiopods, parts I and II: Smithsonian Misc. Coll., v. 127, 1024 p., 269 pls.

Flower, R. H., 1952, New Ordovician cephalopods from eastern North America: Jour. Paleontology, v. 26, pl. 24-59, pls. 5-10.

- 1956, Montoya-Bighorn-Richmond correlations: (Abstract) Geol. Soc. America Bull., v. 67, p. 1793-1794.

Foerste, A. F., 1909, Preliminary notes on Cincinnatian fossils: Denison Univ., Sci. Lab., Bull., v. 14, p. 209-228, pl. 4.

1912, Strophomena and other fossils from Cincinnatian and Mohawkian horizons, chiefly in Ohio, Indiana, and Kentucky : Denison Univ., Sci. Lab., Bull., v. 17, p. 17-139, pls. 1-18.

Hall, James, 1847, Palæontology of New York, v. 1, 338 p., 33 pls.

Hall, James, and Clarke, J. M., 1892, Paleontology of New York, v. 8, pt. 1, 367 p., 20 pls.

Jaanusson, V., 1944, Übersicht der stratigraphie der Lyckholmkomplexstufe: Comm. géol. Finlande Bull., no. 132, p. 92-100.

Ladd, H. S., 1929, The stratigraphy and paleontology of the Maquoketa shale of Iowa: Iowa Geol. Survey, v. 34, p. 305-417, pls. 4-12.

McEwan, E. D., 1920, A study of the brachiopod genus Platystrophia: U. S. Natl. Mus. Proc., v. 56, p. 383-449, pls. 42-52. 
Meek, F. B., 1873, Descriptions of fossils of the Silurian and Deronian system : Ohio Geol. Survey, v. I, pt. II (Paleontology), p. 1-242, pls. 1-23.

Merriam, C. W., and Anderson, C. A., 1942, Reconnaissance survey of the Roberts Mountains, Nevada: Geol. Soc. America Bull., v. 53, p. 1675-1727, 4 pls.

Miller, S. A., 1882, Description of two new genera and eight new species of fossils from the Hudson River group, with remarks upon others: Cincinnati Soc. Nat. History Jour., v. 5, p. $34-44$, pl. $1,2$.

Nolan, T. B., Merriam, C. W., and Williams, J. S., 1956, The stratigraphic section in the vicinity of Eureka, Nevada: U. S. Geol. Survey, Prof. Paper 276, 77 p.

Őpik, A., 1934, Ưber klitamboniten : Tartu Ulikooli. GeoloogiaInstituudi Toimetused, no. 39, 190 p., 48 pls.

Öpik, A., and Laasi, A., 1937, Geologie von Läänemaa : Tartu Ulikooli Geoloogia-Instituudi Toimetused, no. 51, p. 20-29.

Raymond, P. E., 1916, Expedition to the Baltic provinces of Russia and Scandinavia; Part I, the correlation of the Ordovician strata of the Baltic basin with those of eastern North America: Harvard Coll. Mus. Comp. Zoology Bull. 56, p. 179-286.

Ross, C. P., 1934, Correlation and interpretation of Paleozoic stratigraphy in south-central Idaho: Geol. Soc. America Bull., v. 45, p. 937-1000.

1937, Geology and ore deposits of the Bayhorse region, Custer County, Idaho: U. S. Geol. Survey Bull. 877, 161 p. - 1947, Geology of the Borah Peak quadrangle, Idaho: Geol. Soc. America Bull., v. 58, p. 1085-1160.

Ruedemann, R., 1947, Graptolites of North America : Geol. Soc. America, Mem. 19, 527 p., 92 pls.

Savage, T. E., 1917, Stratigraphy and Paleontology of the Alexandrian Series in Illinois and Missouri : Illinois Geol. Survey Bull. 23, p. 67-160, pls. 1-9.

Schuchert, C., and Cooper, G. A., 1932, Brachiopod genera of the suborders Orthoidea and Pentameroidea: Yale Peabody Mus. Nat. History Mem., v. 4, pt. 1, 270 p., 29 pls.
Shaler, N. S., 1876, On the fossil Brachiopoda of the Ohio Valley: Kentucky Geol. Survey Mem., v. I, pt. 3, 44 p., 7 pls. Sinclair, G. W., 1956, Review of A. K. Miller, Ordovician cephalopod fauna of Baffin Island, Geol. Soc. America Mem. 62: Am. Jour. Sci., v. 254, p. 126-128.

Teichert, C., 1930, Die cephalopoden-fauna der Lyckholm-stufe des Ostbaltikums : Palaeont. Zeitschr., v. 12, p. 264-312.

Treece, W. A., 1955, Estimation of vertical exaggeration in stereoscopic viewing of aerial photographs: Photogrammetric Engineering, v. 21, no. 4, p. 518-527.

Twenhofel, W. H., 1916, Expedition to the Baltic provinces of Russia and Scandinavia, 1914-Part 2, The Silurian and high Ordovician strata of Esthonia, Russia, and their faunas; Part 3, An interpretation of the Silurian section of Gotland: Harvard Coll. Mus. Comp. Zoology Bull. 56, p. 289-354.

1927, Geology of Anticosti Island: Canada Geol. Survey Mem. 154, 351 pp., 60 pls.

Ulrich, E. O., and Cooper, G. A., 1938, Ozarkian and Canadian Brachiopoda: Geol. Soc. America, Spec. Paper 13, 323 p., 57 pls.

Umpleby, J. B., Westgate, L. G., and Ross, C. P., 1930, Geology and ore deposits of the Wood River Region, Idaho: U. S. Geol. Survey Bull. 814, 250 p.

Wang, Y., 1949, Maquoketa Brachiopoda of Iowa: Geol. Soc. America Mem. 42, 55 p., 12 pls.

Whittard, W. F., and Barker, G. H., 1950, The Upper Valentian brachiopod fauna of Shropshire, Part I, Inarticulata, Protremata, and Orthoidea: Ann. and Mag. Nat. History, 12 th ser., $\nabla .3$, no. 31 , p. 553-589, pls. V-VIII.

Williams, A., 1951, Llandovery brachiopods from Wales with special reference to the Llandovery District: Quart. Jour. Geol. Soc., v. 107, p. 85-136, pls. III-VIII.

Winchell, N. H., and Schuchert, C., 1895, The lower Silurian Brachiopoda of Minnesota: Geology of Minnesota, v. 3, p. $333-474$, pl. 29-34. 
$=$ 


\section{INDEX}

[Italic numbers indicate descriptions]

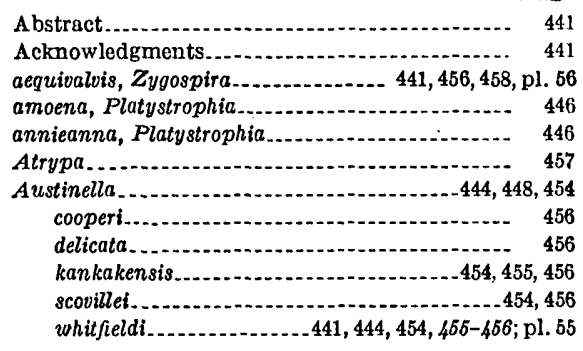

Bayhorse quadrangle..

443

bellilamellosus, Plaesiomys

445,454

Bighorn dolomite.

Borah Peak quadrangle

Boreadorthis.

brachiophorus, Orthambonites.

capax, Lepidocyclus.

clarksvillensis, Platystrophia.-._-...-.-.-. 446

colbiensis, Platystrophia......................... 446

Collecting localities, fossils.......................441-443

cooperi, Austinella............... 456

delicata, Austinella.................................. 456

Diceromyonia tersa ..................... 445, 468; pl. 56

Dolerorthis plicata....................................... 448

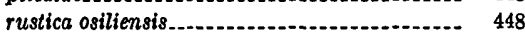

elegantula, Platystrophia......................... 446 equiconvexa, Platysirophia...................... 445, 446 extensa, Platystrophia........................... 446

facula, Sceptropora

441,445

Fauna, age ... 444-445 composition and signiflcance................ 444 ecologic significance......................... 445-446

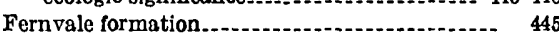

Fish Haven dolomite............................ 443

Formic acid, use on small rock samples.......... 441

Fossils, collecting localities.
Glyptorthis pulchra Graptolites.......... 443, 444 Hanson Creek formation. ..................... 443, 444 Hesperorthis............................ 444, 446-447, 448 onniensis........................................ 448

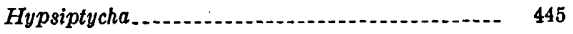

Introduction.

iphigenio, Ploesiomeso

iphigenia, Plaesiomys.......................... 440

jupiterensis, Zygospira 44

kankakensis, Austinella. $454 ; 455,456$ Orthis kentuckiensis, Zygospira-....... 458 Kinnikinic quartzite............................. 443 lebanonensis, Zygospira............... 444, 445, 458; pl. 56 Lepidocyclus..................................... 444 capax $\begin{array}{ll}\text { capax } & \\ \text { rectangularis } & 446\end{array}$ Lordorthis variabilis n. sp..........- 444, 445, 446, 447, 448

Maclurites.

meedsi, Plaesiomys Mount Hamilton, Nevada..................... 443

Occidentalis

onniensis, Hesperorthis

448

Orthambonites brachiophorus........................ $\quad 448$

Orthis kankakensis................................ 454 subquadratus.................................... 449

whitfieldi

osiliensio, Dolerorthis rustica .

Phl Kappa formation

Plaesiomys bellilamellosus

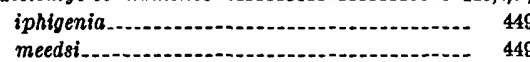

subquadratus............................ 441, 449-454 idahoensis $\mathrm{n}$, subsp

Platystrophia amoena........................... 446 annieanna................ 446 clarksoillensis.................................. 446 colbiensis_. _...

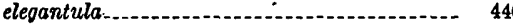
equiconvexa............................... 445, 446 extensa...
Page

Plectorthis........................................ 454 punctata.......................................... 455 plicata, Dolerorthis pulchra, Glyptorthis . punctata, Plectorthis......................... 455 putilla, Zygospira.............. 444, 445, 456, 457; pl. 56

Rafinesquina sp................................... 445 Ramshorn slate.......... Receptaculites rectangularis, Lepidocyclus. recurvirostris, Zygospira..................... 441, 445, 457 References cited............................... 458-459 Resserella tersa.................. 458 Resser ella tersa resupinata, Zygospira
Rhynchonellacea robustum, (Grewinkia) Streptelasma.............. 445 rustica osiliensis, Dolerorthis........................ 448

Sceptropora facula.............................. 441, 445 Scope of investigation. ........................... 441 scovillei, Austinella................................. 454, 456 Stereophotography, of specimens........... 441 Streptelasma (Grewinkia) robustum............... $\quad 445$ Strophomena sp.................................... $\quad 445$ Strophomenacea.......................... 458; pl. 55 subquadratus, Orthis............................. 449 Plaesiomys . . ............. 441, 449-454

tersa, Diceromyonia....................... 445, 458; pl. 56

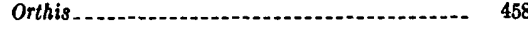
Resserella ....................................... 458

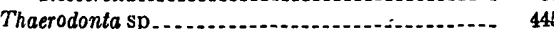
variabilis, Lordorthis................. 444, 445, 446, 447, 448 whitfieldi, Austinella........ 441, 444, 454, 455-456; pl. 55 Orthis .

Zyoospira aequivalvis ..... 441,458 circularis..................... 444, 445, 467-458; pl. 56 jupiterensis.

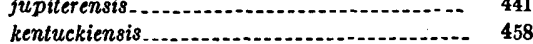
lebanonensis...................... 444, 445, 458; pl. 56 putilla................... 444, 445, 456, 457 ; pl. 56 recurvirostris ............................ 441,445, 467 resupinatos. 


\section{PLATES 54-56}

[All specimens have been photographed stereoscopically. Detalls on several specimens cannot be seen with the unaided eye but can be made out with a pocket stereoscope.] 


\section{PLATE 54}

[All fgures natural size except as indicated]

Figures 1, 2, 4-6, 8-11, 13-17, 19-25, 27, 28, 31, 32, 35, 36. Lordorthis variabilis Ross n. sp. (p. 447).

1, 2, 5, 9. Holotype, dorsal, lateral, posterior, and ventral views, loc. D240 CO, USNM 133227.

4, 8. Pedicle valve of transverse, finely ribbed variety, paratype, loc. D238 CO, USNM 133228.

6, 10. Immature brachial valve, X3, paratype, loc. D240 CO, USNM 133229.

11, 15, 17, 20. Immature complete specimen, showing Hesperorthis-like form, paratype, loc. D306 CO, USNM 133230.

13, 19. Pedicle valve of elongate, poorly ribbed variety, paratype, loc. D240 CO, USNM 133230.

14, 16. Pedicle valve with arched deltidial plate, paratype, loc. D240 CO, 133232.

21. Brachial valve, showing simple cardinal process and Hesperorthis-like brachiophores, paratype, loc., D240 CO USNM 133233.

22, 25, 28, 32. Immature specimen, complete, X2, paratype, loc. D240 CO, USNM 133234.

23, 24. Pedicle valve, showing deltidial plate isolated exteriorly by shell material added to sides of delthyrium. Plate growing forward beneath this material. Paratype, loc. D240 CO, USNM 133235.

' 27, 31, 36. Very small, immature specimen, $\times 3$, showing lamelose surface. Paratype, locality D240 CO, USNM 133236.

35. Small brachial valve showing arched chilidium, paratype, locality D240 CO, USNM 133237.

3, 7, 12, 18. Zygospira cf. Z. recurvirostris (Hall), $\times 3$ (p. 457). Locality D237b CO, USNM 133238

26. Hesperorthis onniensis Whittard and Barker (p. 448). Latex cast of the holotype, GSM 82515. See Whittard and

Barker, 1950, pl. 6, fig. 9. From Upper Valentian Purple Shales of the Onny River section, Shropshire.

29, 30, 33, 34, 37, 38, 41, 42. Plaesiomys subquadratus subsp. idahoensis Ross n. subsp. (p. 249).

29, 30, 33, 34. Holotype, locality D237b CO, USNM 133239.

37, 38. Pedicle valve, paratype, more coarsely ribbed than holotype, locality D240 CO, USNM 133240.

41, 42. Brachial valve, paratype, more coarsely ribbed than holotype, locality D240 CO, USNM 133241.

39, 40. Glyptorthis cf. G. pulchra Wang. (p. 448). Brachial valve, locality D240 CO, USNM 133244. 




BRACHIOPOD FAUNA OF SATURDAY MOUNTAIN FORMATION 


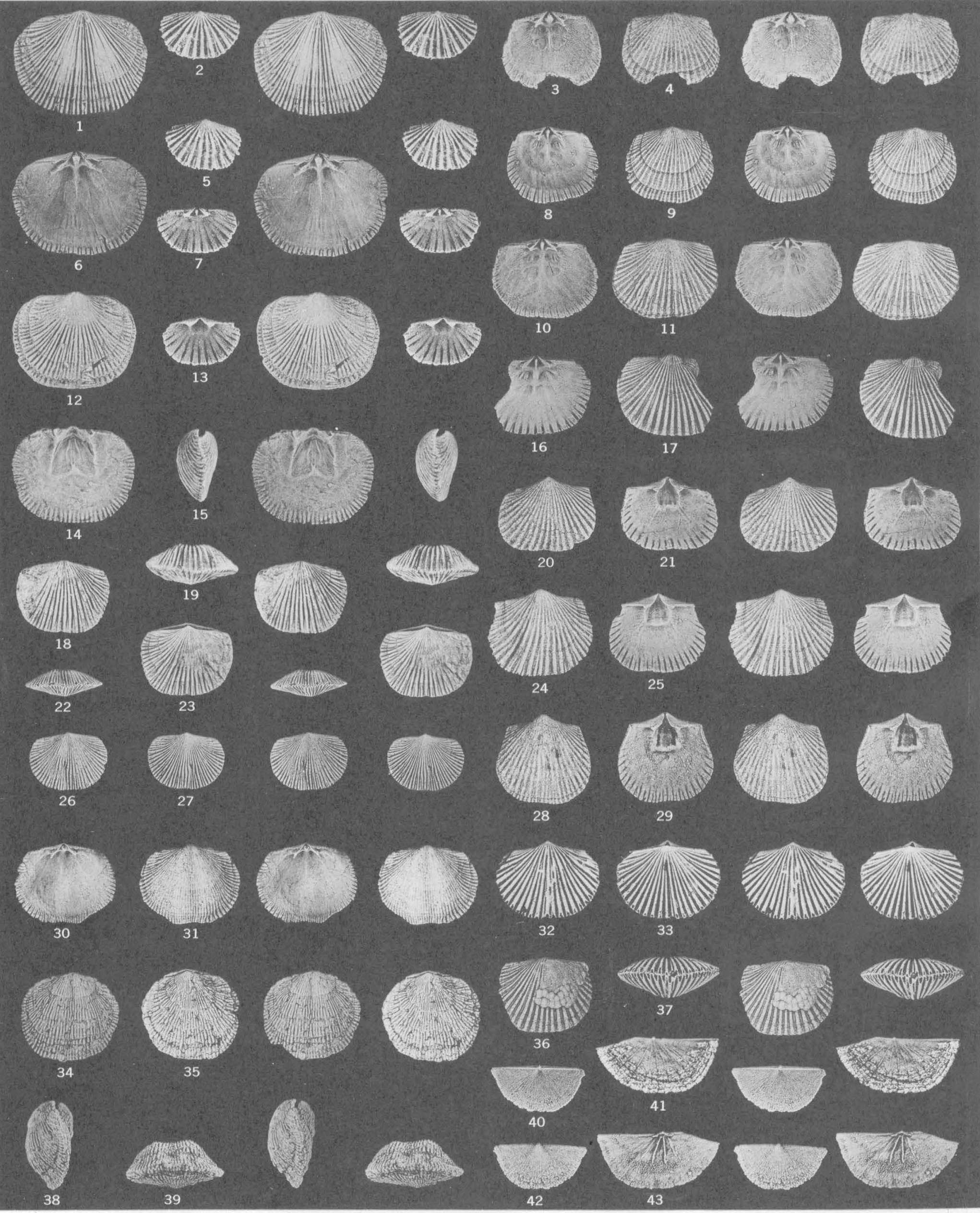




\section{PLATE 55}

[All figures natural size except as indicated]

Frgures 1, 6, 12, 14, 15, 18, 19, 23. Plaesiomys subquadratus (Hall) (p. 449). Three specimens from Hall's (1847) type lot. AMNH 913/6. "Hudson River group", Cincinnati, Ohio.

1, 6. Brachial valve (Hall, 1847 , pl. $32 \mathrm{~A}$, fig. 10).

12, 14. Pedicle valve (Haill, 1847, pl. 32A, fig. 11, $\mathrm{m}$ )

15, 18, 19, 23. Complete specimen (Hall, 1847, pl. 32A, figs. 1a, f. d).

22, 26, 27, 30, 31. Plaesiomys subquadratus subspecies idahoensis Ross, n. subsp. (p. 449).

22, 26, 27. Immature specimen, locality D237b CO, USNM 133242.

30, 31. Brachial valve, finely ribbed in median section, possibly pathologic, paratype, locality D240 CO, USNM 133243.

34, 35, 38, 39. Plaesiomys cf. $P$. bellilamellosus Wang, complete specimen, locality D312 CO, USNM 133245 (p. 454).

2-5, 7-11, 13, 16, 17, 20, 21, 24, 25, 28, 29, 32, 33, 36, 37. A ustinella aff. A. whitfieldi Winchell and Schuchert (p. 455).

2, 7. Smallest brachial valve obtained, $\times 3$. Part of same specimen as figures 5, 13, locality D240 CO, USNM 133246.

3 , 4. Brachial valve of transverse variety, with large myophore and relatively simple ribbing, locality D240 CO, USNM 133248.

5, 13. Smallest pedicle valve obtained, $\times 3$. Same specimen as figures 2, 7, locality D240 CO, USNM 133247.

8 , 9. Brachial valve of elongate variety, with small myophore, bifurcating costae, and a fine costella between costae, locality D240 CO, USNM 133249.

10, 11. Brachial valve of transverse variety, with small myophore, bifurcating costae, and a fine costella between costae, locality D306 CO, USNM 133250.

16,17 . Brachial valve of transverse variety, with virtually no myophore, intercalated costae, and a fine costella between costae, locality D203 CO, USNM 133251.

20,21 . Pedicle valve of transverse variety, with relatively simple costae, locality D240 CO, USNM 133252.

24, 25. Pedicle valve with bifurcating costae, locality D240 CO, USNM 133253.

28,29 . Pedicle valve of elongate variety, with bifurcating costae, locality D240 CO, USNM 133254.

$32,33,37$. Immature specimen, $\times 2$, locality D237 CO, USNM 133255.

36. Brachial valve with simple costae, fine costella between costae, and pits on costae, locality D237b CO, USNM 133256.

40, 42. Thaerodonta sp. or Sowerbyella sp., $\times 2$, locality D240 CO, USNM 133257 (p. 458).

41, 43. Thaerodonta sp., brachial valve, X2, locality D240 CO, USNM 133258 (p. 458). 


\section{PLATE 56}

All figures natural size except as indicated

Figdres 1, 2, 5, 6, 7, 8. Platystrophia cf. P. equiconvexa Wang (p. 446).

1. Brachial valve, $\times 1$, with front margin broken, locality D238 CO, USNM 133259.

2, 5, 6. Brachial valve, not full grown, $\times 1$, locality D313 CO, USNM 133260.

7, 8. Pedicle valve, immature, $\times 1$, locality D316 CO, USNM 133261.

3, 4, 9, 10. Zygospira recurvirostris (Hall) (p. 457).

Type specimen, $\times 3$, from Trenton limestone, Martinsburg, N. Y., AMNH 705/3. (Hall, 1847, pl. 33, figs. 5 a-c.)

11, 12. Zygospira putilla Hall and Clarke (p. 457). $\times 3$, locality D203 CO, USNM 133262.

13, 14, 15. Zygospira aequivalvis Twenhofel.

$\times 3$, English Head formation, east bank of the Capelin River, Anticosti Island, YPM 20194.

16, 17. Zygospira aff. Z. putilla Hall and Clarke (p. 457). $\times 3$, locality D240 CO, USNM 133263.

18, 19, 20, 25, 26. Glyptorthis cf. G. pulchra Wang, $\times 1$ (p. 448).

18,25 . Brachial valve of an old specimen, from same individual as figure 26. Note tectonic deformation near margin. Locality D238 CO, USNM 133264.

19, 20. Pedicle valve, locality D240 CO, USNM 133266.

26. Pedicle valve of an old specimen, slightly deformed by lateral compression which seems to have caused a false sulcus at anterior margin. Same individual as figures 18,25 . Locality D238 CO, USNM 133265.

21, 22, 23, 24, 27, 28. Zygospira cf. $Z$. circularis Cooper, $\times 3$ (p. 457).

21-23. Subelliptical specimen, locality D237b CO, USNM 133267.

24, 27, 28. Subcircular specimen, locality D240 CO, USNM 133268.

29, 30. Unidentified rhynchonellid, immature, $\times 3$, locality D240 CO, USNM 133271 (p. 456)

31, 32, 35, 36, 37, 38, 41, 42. Zygospira cf. Z. lebanonensis Cooper (Compare with pl. 56, figs. 13, 14, 17) (p. 458). $31,32,35,36$. Small specimen, $\times 3$, locality D240 CO, USNM 133269 .

$37,38,41,42$. Specimen with "median" rib off-center, $\times 3$, locality D240 CO, USNM 133270.

$33,34,39,40,43,44$. Diceromyonia cf. D. tersa (Sardeson), $\times 2$, locality D240 CO (p. 458).

$33,34,39,40$. Complete specimen, USNM 133272 .

43. Brachial valve, USNM 133273.

44. Pedicle valve, USNM 133376. 


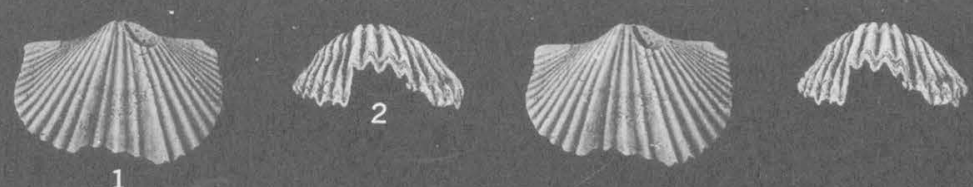
1

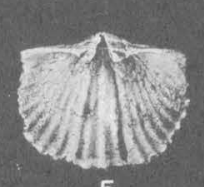

5

(2) $)$ (3) 7

\&iv

11

(iv)

16

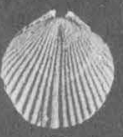

21

$\underset{23}{\text { quiliti }}$

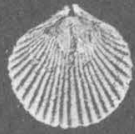

27

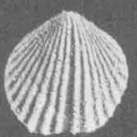

31

$(1)$

quin)

37

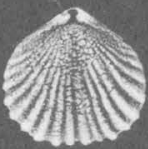

41 y)

6

Wully

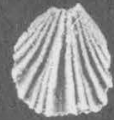

12
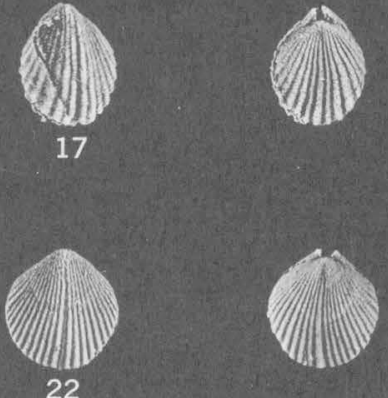

는
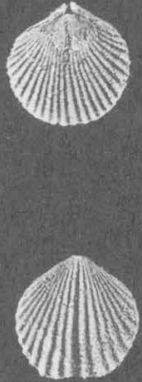

(1)

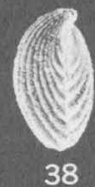

Giili,

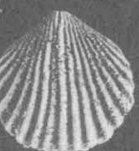

42
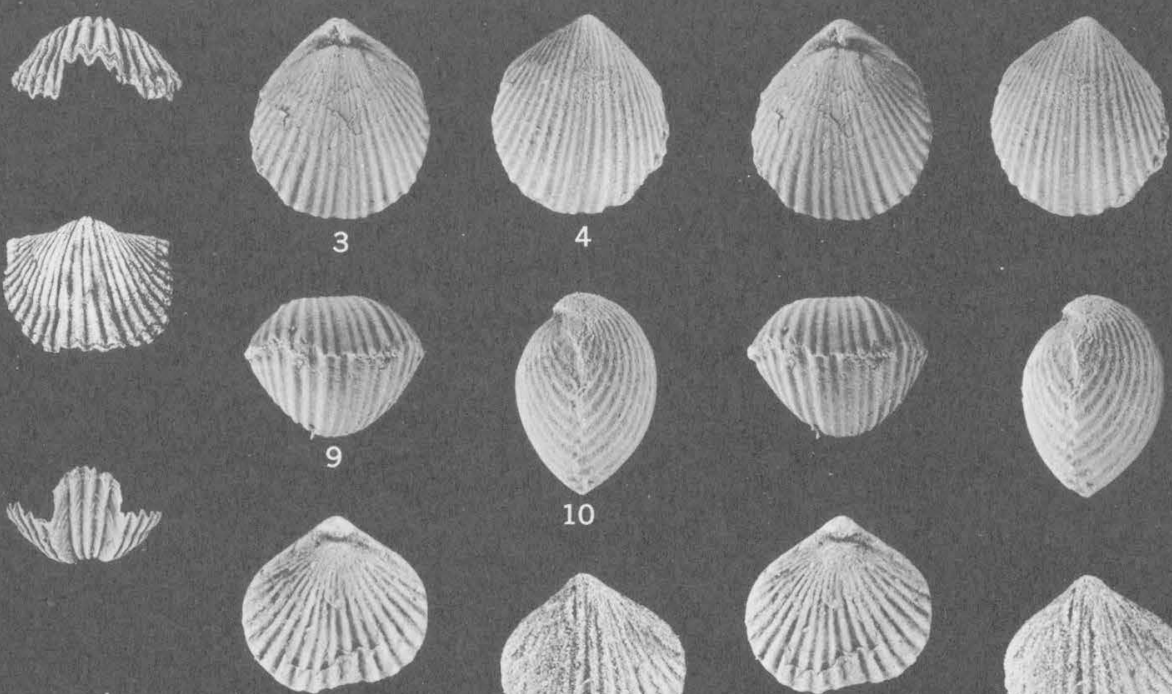

y)

13

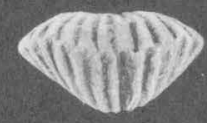

(1)

15
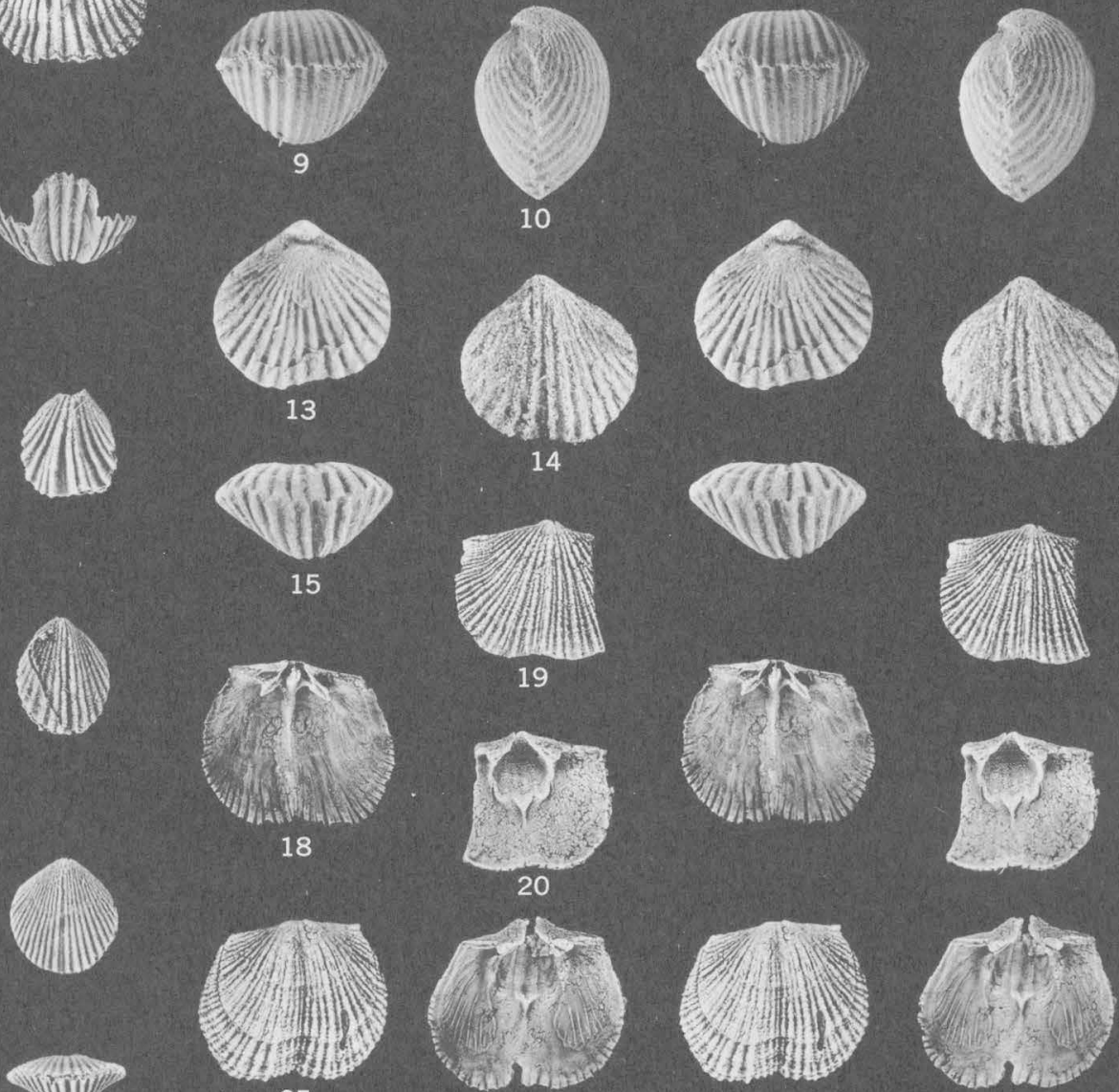

25
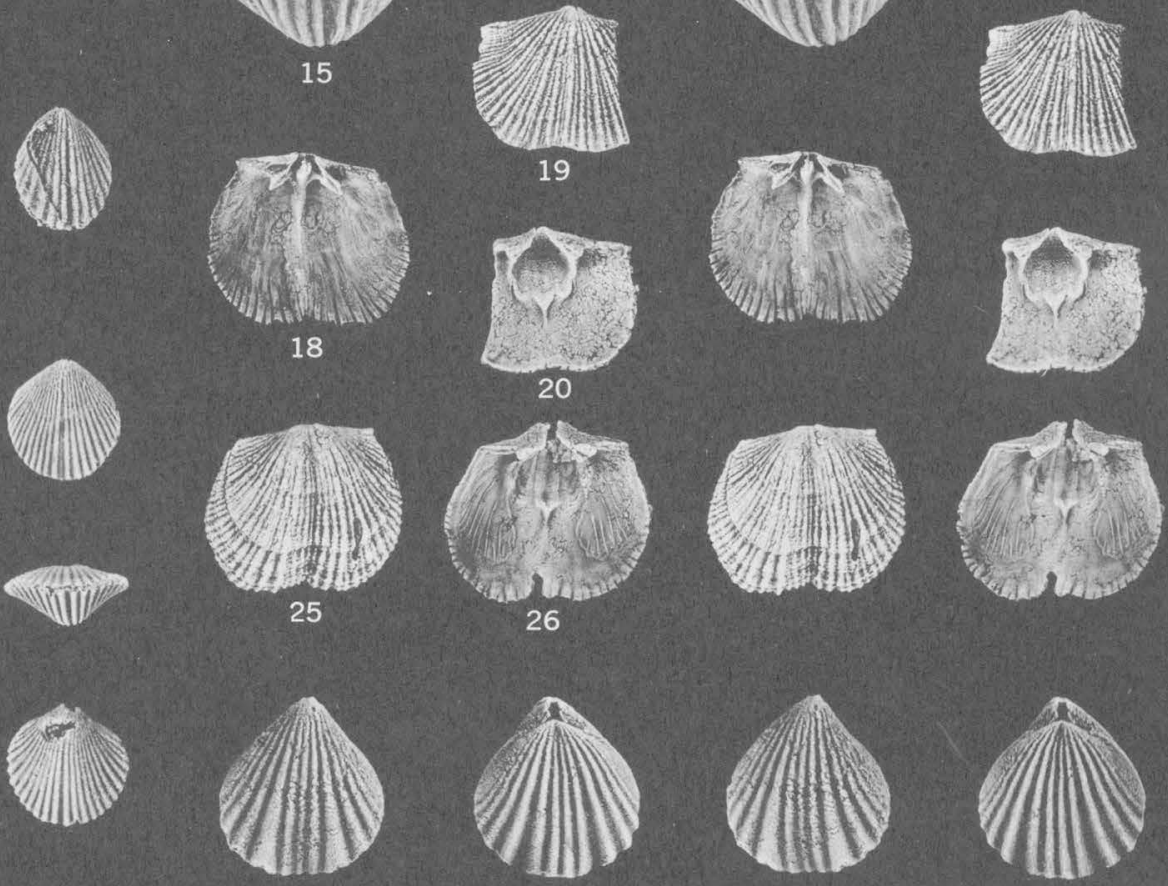

29
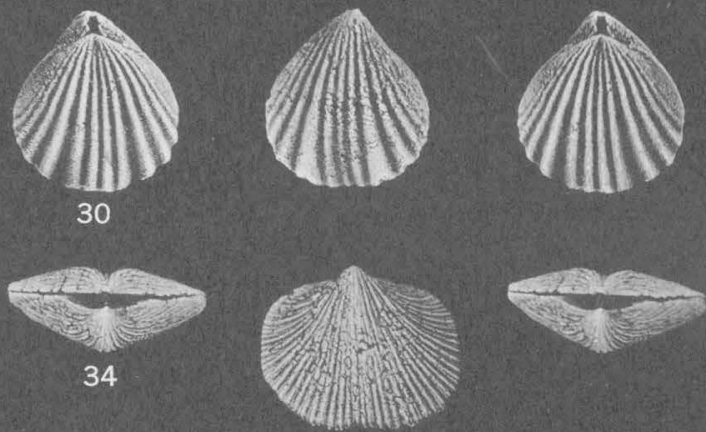

(aiv

33
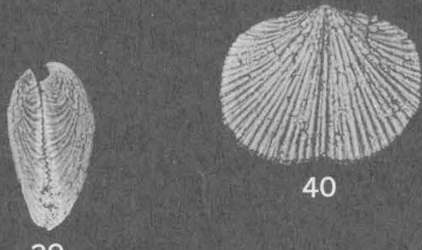

40
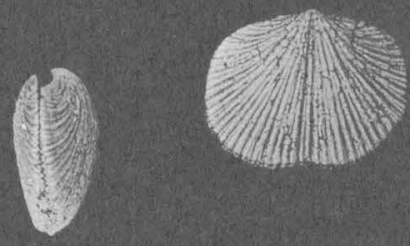

39
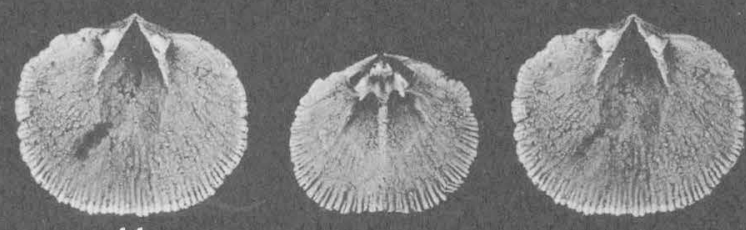